\title{
Regional differences in quality of krill and fish as prey along the Western Antarctic Peninsula
}

\author{
Kate E. Ruck*, Deborah K. Steinberg, Elizabeth A. Canuel
}

Virginia Institute of Marine Science, College of William \& Mary, PO Box 1346, Gloucester Point, VA 23062, USA

\begin{abstract}
The warming trend in the northern part of the Western Antarctic Peninsula (WAP) has led to a decrease in perennial and summer sea ice, an increase in heat content over the shelf, and lower phytoplankton biomass, which could affect the prey quality of krill and fish that are utilized by apex predators. We compared prey quality metrics, including elemental $(C, N)$ content; total, neutral, and polar lipid content; and energy densities of known penguin prey items including krill (Euphausia superba, Thysanoessa macrura, and E. crystallorophias) and fish (silverfish Pleuragramma antarcticum and the myctophid Electrona antarctica) along the WAP latitudinal gradient each January from 2009 to 2011. E. antarctica had the highest prey quality in terms of lipid content and energy density, followed by T. macrura and P. antarcticum, then E. crystallorophias and E. superba. For all species, variations in $\mathrm{C}$ and $\mathrm{N}$ content were most strongly correlated with the animals' neutral lipid content, in that animals with the larger neutral lipid stores had significantly higher $\mathrm{C}$ and lower $\mathrm{N}$ content. Across all sexes and maturity stages, $E$. superba in the southern study region had ca. $20 \%$ higher total lipid content than E. superba in the north, and a stepwise multiple linear regression analysis showed that latitude, sexual differences, and upper water column temperatures best explained this regional difference in lipid content. This regional variability in $E$. superba prey quality could affect the ability of apex predators that rely on $E$. superba to meet their energetic demands, and should be considered in future modeling efforts.
\end{abstract}

KEY WORDS: Krill · Euphausia superba $\cdot$ Silverfish · Myctophid · Lipid content · Prey quality · Antarctic Peninsula

Resale or republication not permitted without written consent of the publisher

\section{INTRODUCTION}

The ecosystem dynamics of waters along the continental shelf of the Western Antarctic Peninsula (WAP) are dominated by the seasonal advance and retreat of sea ice, which in turn dictates the development of a strong summer phytoplankton bloom, forming the base of an energy-rich marine food web (Prézelin et al. 2000, Vernet et al. 2008, Steinberg et al. 2012). Krill are well recognized as an important trophic link in this region, serving as prey for higher predators such as penguins, seals, and whales (Costa \& Crocker 1996, Fraser \& Trivelpiece 1996). Predation on fish by animals classified as highly specialized krill predators can help sustain them through years of low krill abundance and can be energetically beneficial when provisioning young during key periods of growth (Ainley et al. 1998, 2003, Chapman et al. 2011, Hückstädt et al. 2012).

Climate change is altering the WAP ecosystem and could potentially influence the availability and nutritional value of these prey items for apex predators. The WAP is among the fastest-warming regions on Earth, with an increase in mid-winter surface atmospheric temperatures of $6^{\circ} \mathrm{C}$ since 1950 (Vaughan et al. 2003). The average temperature of the Upper Circumpolar Deep Water (UCDW), delivered by the Antarctic Circumpolar Current, has also increased since regular sampling began in 1997, and intrusions of this relatively warm water onto the shelf are the 
main source of heat to the water column (Hofmann et al. 1996, Klinck et al. 2004, Martinson et al. 2008, Dinniman et al. 2012). This regional climate-ocean warming of the WAP has led to major changes in perennial sea-ice dynamics, characterized by a significant decrease in ice extent and duration (Stammerjohn et al. 2008, 2012). As a result, a latitudinal 'climate migration' is occurring along the WAP, with a warmer, more humid, sub-polar climate moving south and progressively replacing a cold and dry polar climate (Smith et al. 2003).

This warming of the WAP is affecting the function and structure of the marine pelagic food web at every level, from primary producers to penguins (Prézelin et al. 2000, Ducklow et al. 2012). A comparison of 2 satellite-derived data sets, spanning nearly $30 \mathrm{yr}$ (1978 to 1986 and 1998 to 2006) indicated that summertime surface chlorophyll a ( $\mathrm{chl}$ a) along the far northern WAP declined by approximately $12 \%$ between these 2 time periods, with a stronger sub-regional decrease $(\sim 89 \%)$ in chl a north of $63^{\circ} \mathrm{S}$ and a substantial increase $(\sim 66 \%)$ farther south (Montes-Hugo et al. 2009). Another dramatic example of change in the WAP food web is the $83 \%$ decline in breeding pairs of the native, ice-obligate Adélie penguin Pygoscelis adeliae in the northern WAP, near Anvers Island, since the mid-1970s (Fraser et al. 2013). Suggested mechanisms contributing to this decline include the loss of overwinter pack-ice habitat, degradation of terrestrial summer breeding habitat, and decreases in prey quality and abundance (Chapman et al. 2010, 2011, Trivelpiece et al. 2011, Fraser et al. 2013).

Prey quality is mainly dictated by its energy density, which correlates directly with the animal's lipid content (Clarke 1980). Among seabirds, chick survival and recruitment are often correlated with chick mass as they leave the nest site, and changes in prey quality can contribute to a reduction in fledgling mass and, potentially, a failure in recruitment (Golet et al. 2000, Chapman et al. 2010, 2011). A recent analysis by Chapman et al. $(2010,2011)$ focused on Adélie penguin chick growth in the WAP, using an individual-based energetics model to highlight the importance of higher-quality prey items in chick diets, and showing that a small deficiency of $0.117 \mathrm{~kg}$ in fledging mass could result in a chick's failure to recruit. In these types of energetics studies, the biochemical composition of prey fed to chicks is usually estimated from length-specific literature values. These estimates do not consider the potential effects that increasing temperatures and a changing food base could have on energy storage functions for these mid-trophic level prey species.
The metabolic rates of ectotherms vary with ambient temperature, and a temperature-driven increase in metabolic rates could inhibit the ability of prey species to accumulate and store lipids in a region like the northern part of the peninsula, where phytoplankton is also decreasing (Peck et al. 2004, MontesHugo et al. 2009, Flores et al. 2012). This would alter the length-specific literature values utilized in most modeling studies. Energetics models also rarely address parameters besides total lipid content that contribute to the nutritional value of prey. Jackson \& Place (1990) showed that rockhopper penguins Eudyptes chrysocome have higher assimilation efficiencies for triglycerides relative to wax esters, demonstrating that different lipid classes can impact penguin metabolism. In addition, phytoplankton with high $\mathrm{C}$ to nutrient (N,P) ratios is of low nutritional value to zooplankton. Consumption of phytoplankton with high C:N,P ratios can shift zooplankton elemental composition, forcing zooplankton into a nutrientlimited state, as the C:N,P content of their food is not sufficient to meet their nutritional demands (Van de Waal et al. 2010). The caloric content of krill used in models is usually calculated from other measurements of the animals' biochemical composition, and to date, only 3 studies have directly measured Euphausia superba caloric content (Nagy \& Obst 1992, Ainley et al. 2003, Färber-Lorda et al. 2009). Incorporating relationships between prey quality and predator metabolism into energetics models will increase model accuracy by improving the quality of functions regulating modeled predator growth.

The climate gradient of the WAP makes it a unique region to address how differing environmental parameters can affect prey quality, such that prey in the northern WAP may differ from prey found farther south in terms of species composition or biochemical composition. To assess whether regional warming and subsequent changes in phytoplankton are affecting prey quality along the WAP, we compared total, neutral, and polar lipid content, elemental (C:N) ratios, and energy densities of known Adélie penguin prey items (krill and fish) collected along the WAP latitudinal gradient. Comparing prey quality metrics from different years and regions with different environmental characteristics allowed us to examine whether changes in prey physiology are related to parameters such as water temperature and chl a. These relationships will be useful in future modeling efforts used to predict effects of regional warming on prey quality, enhancing our understanding of food web energy transfer in this dynamic ecosystem. 


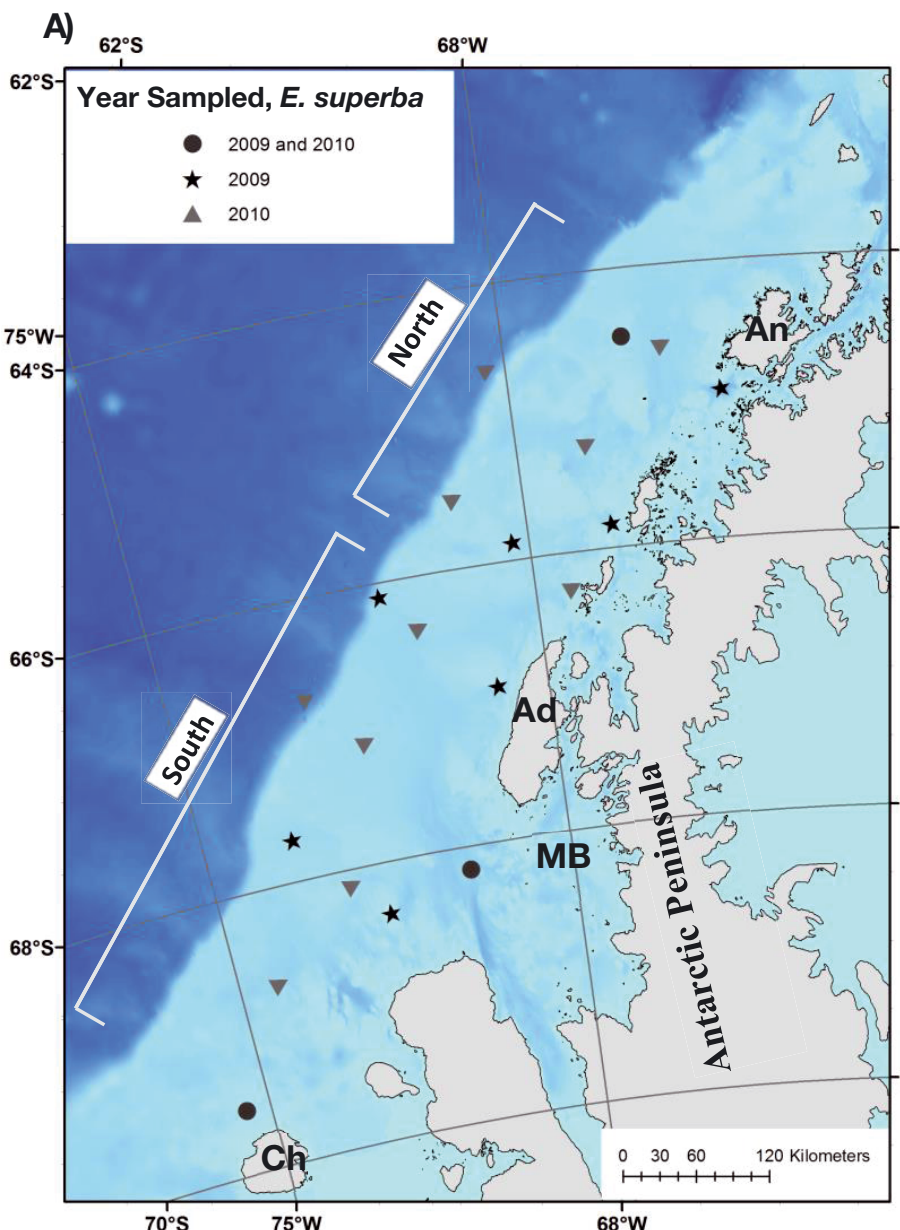

B) $62^{\circ} \mathrm{s}$

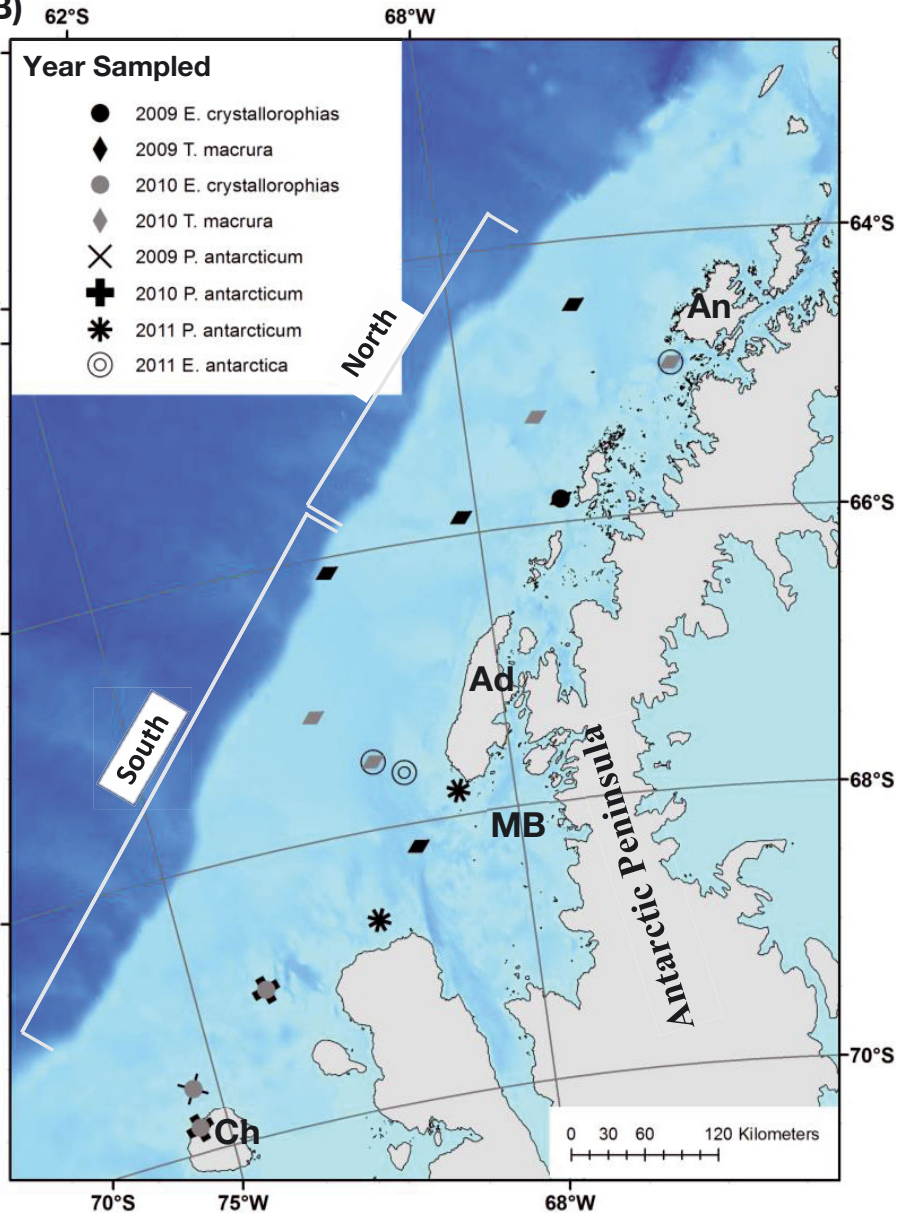

Fig. 1. Palmer Antarctica Long-Term Ecological Research study region and stations sampled. Collection sites for (A) Euphausia superba and (B) E. crystallorophias, Thysanoessa macrura, Pleuragramma antarcticum, and Electrona antarctica. An: Anvers Island, Ad: Adelaide Island, MB: Marguerite Bay, Ch: Charcot Island. The North and South regions used for comparative analysis are indicated by brackets (note: 'North' is all stations north of, but not including, the '300' sampling line in Ducklow et al. 2012). Shades of blue are used to illustrate the bathymetry, with light blue representing the continental shelf and dark blue the continental slope and abyssal plain. The continental shelf is roughly $200 \mathrm{~km}$ wide and averages $430 \mathrm{~m}$ in depth (Ducklow et al. 2012)

\section{MATERIALS AND METHODS}

\section{Study area and sample collection}

Krill and fish used for prey quality analyses were collected on the annual austral summer cruises of the Palmer Antarctica Long-Term Ecological Research (PAL LTER) program aboard the ARSV 'Laurence M. Gould' each January from 2009 to 2012 (Ducklow et al. 2012). We divided the study grid into 'North' and 'South' sub-regions (Fig. 1) based on existing sea-ice dynamics described by Stammerjohn et al. (2008), and an apparent difference in Adélie penguin diet between these 2 regions (W. Fraser pers. comm.).

We collected macrozooplankton using a $2 \times 2 \mathrm{~m}$ square-frame net (700 $\mu \mathrm{m}$ mesh), towed obliquely from the surface to $120 \mathrm{~m}$ (Ross et al. 2008, Bernard et al. 2012). When the bottom depth of a station was less than $120 \mathrm{~m}$, the net was fished to $\sim 20 \mathrm{~m}$ above the sea floor. The volume of water filtered through the net was determined with a General Oceanics flow meter. Once on board, the contents of the cod end were gently transferred to a large tub filled with ambient surface seawater, and krill or fish species of interest were removed. We focused on organisms that were previously identified as important prey items for penguins in colonies along the WAP (W. Fraser pers. comm.), including 3 krill species (Euphausia superba, E. crystallorophias, Thysanoessa macrura) and 2 fish species (the myctophid Electrona antarctica and the Antarctic silverfish Pleuragramma antarcticum). Animal lengths were recorded with a set of digital calipers for E. su- 
perba (standard length 1, the length from the eyes to the tip of a uropod; Mauchline 1970), and fish (standard length, the length between the most forward part of the head and the posterial end of the hypural bone; total length, the length between the most forward part of the head and the end of the caudal fin rays; Ricker \& Westrheim 1979), and sex/maturity stage was determined for E. superba (Makarov et al. 1981). Total lengths for T. macrura and E. crystallorophias were calculated from wet weights based on literature values (Färber-Lorda 1994, Mayzaud et al. 2003, Ju \& Harvey 2004). All animals for prey quality analyses were then frozen and stored at $-80^{\circ} \mathrm{C}$.

Krill collected in 2009 and 2010 span the entire sampling grid and represent the majority of the data presented here. Fish were rarely collected, and thus cover a limited geographic and temporal range (1 sample in 2009, 5 in 2010, and 17 in 2011). As the grid was sampled from north to south over the course of $5 \mathrm{wk}$, a comparison was conducted in 2010 and 2012 in which E. superba were collected from one of the northern-most stations at the beginning and end of the cruise (6 and 31 January 2010; 6 and 30 January 2012) to determine whether the seasonal progression of summer was potentially biasing observed longitudinal trends.

\section{Prey quality analyses}

In the laboratory, animals were either analyzed individually or combined with other animals of the same species and physical characteristics (e.g. size, sex) to form representative composite samples for individual sampling stations. T. macrura composite samples consisted of 10 individuals, E. crystallorophias of 5 individuals, and juvenile E. superba of 2 individuals; all fish were analyzed individually. To test whether the composite samples were artificially altering variance, we analyzed half of the mature $E$. superba as individuals and half as 2-individual composites. An F-test was then used to compare the variances between these 2 groups, and no significant differences were found for any of the prey metrics. This confirmed that the variances associated with the composite samples were representative of individual adult E. superba in nature. Artificial composites were then created by averaging prey metric values of 2 morphometrically similar individual E. superba samples of the same sex to use in data analysis along with the 2-individual E. superba composites.

Sample wet weights were determined with a Sartorius BP211D analytical balance, and samples were then homogenized either using a Misonix ultrasonic liquid processor XL-2000 series or a Virtis '45' homogenizer. The samples were then freeze-dried using a Labconoco Freezone 6 Liter Plus freeze dryer and dry weights (DW) were determined. Sub-samples of the dry, homogenous powder were taken for the various prey quality analyses.

To determine total organic $\mathrm{C}$ and $\mathrm{N}$ content, $\sim 50 \mathrm{mg}$ sub-samples of freeze-dried, homogenized tissues were placed in a desiccator with a small beaker of concentrated $\mathrm{HCl}$ for $16 \mathrm{~h}$ to remove inorganic $\mathrm{C}$, and then moved to a $60^{\circ} \mathrm{C}$ drying oven for a minimum of $72 \mathrm{~h}$. The acidified samples were then weighed, packed into tin capsules, and analyzed using a Costech ECS 4010 CHNSO Analyzer with flash combustion using acetanilide as the standard.

We concentrated the majority of our analysis efforts on animal lipid content in order to provide detailed prey quality data (e.g. stage, sex, length) that can be used in energetics models, but also calculated caloric values to provide additional energetics information. Analyzing neutral and polar lipid concentrations separately enabled us to determine the relative influence of each in driving any observed trends in total lipids, as some krill use both lipid classes as storage lipids (Hagen et al. 1996, Ju et al. 2009). Neutral and polar lipid classes were extracted and separated utilizing a modified accelerated solvent extraction method developed by Poerschmann \& Carlson (2006). Briefly, each sample was placed in a cell with a silicabased sorbent at its outlet, and the cell was pressurized and cycled through $2 n$-hexane/acetone (9:1, $\mathrm{v} / \mathrm{v}$ ) extractions at $50^{\circ} \mathrm{C}$ to collect the neutral lipids followed by 2 chloroform/methanol (1:4, v/v) extractions at $80^{\circ} \mathrm{C}$ to collect the polar lipids. Each fraction was then dried completely under $\mathrm{N}_{2}$ gas and resuspended in $500 \mu \mathrm{l}$ of hexane for the neutral fraction and $2000 \mu \mathrm{l}$ of chloroform for the polar fraction. The final lipid concentration of each fraction was determined gravimetrically using a Sartorius XP1000P microbalance.

To determine caloric/energy content, a subsample of freeze-dried, homogenized tissue was formed into a pellet and ignited in a bomb calorimeter (Parr Instrument, Model 6300) using benzoic acid as a standard. We only directly measured caloric/energy content for adult E. superba and our fish samples because there was not enough dry mass in an individual T. macrura, E. crystallorophias, or juvenile $E$. superba sample to run on a standard bomb calorimeter. Instead, caloric values for these groups were calculated using published equations from FärberLorda et al. (2009). 


\section{Data analysis}

Statistical differences between prey species, years, and North-South sub-regions sampled were calculated using a 2-way ANOVA when data met assumptions of normality and homogeneity. A 2-sample $t$-test was used to examine data sets that only spanned 1 yr or 1 region. Data sets that did not conform to a normal distribution were ln-transformed. Data that did not meet the normality assumption after transformation were tested with the non-parametric Mann-Whitney test. These data analyses were performed in the $\mathrm{R}$ statistical programming language (www.r-project.org).

Stepwise multiple linear regression models were used to assess the relative importance of several environmental and temporal forcing factors in affecting latitudinal trends in E. superba prey quality metrics ( $\mathrm{N}$ and $\mathrm{C}$ content; neutral, polar, and total lipid content). Potential variables used in the model included: year, sex (analyzed as a categorical variable: juvenile, male, female), latitude (analyzed as a continuous variable), 0-120 m integrated chl $a, 0-120 \mathrm{~m}$ integrated primary production, $0-120 \mathrm{~m}$ average water temperature, and day of the year of sample collection. Measurements of discrete chl a (taken every $15 \mathrm{~m}$ of depth, on average), primary production (taken every $20 \mathrm{~m}$ of depth, on average), and water temperature (taken continuously via CTD) at every station where prey were collected were obtained from the PAL LTER database (www.pal.lternet.edu/data/). Discrete chl $a$ and primary production values were integrated over the top $120 \mathrm{~m}$ to use in the regression analyses. All regression analyses were performed using SAS statistical software. Significance for all statistical analyses was determined at $\alpha=0.05$.

\section{Data visualization}

Maps were created with ArcGIS 10 Geostatistical Analyst to visualize $120 \mathrm{~m}$ integrated chl $a$ and mean water temperatures for the PAL LTER study region. Temperature interpolations were created with ordinary kriging, and chl a interpolations were created with the inverse distance weighted method. Oceanographic stations from the PAL LTER cruise with available water temperature and chl a data were used in the analysis to increase the accuracy of the interpolations (stations depicted in Fig. 2). Regression analyses only utilized data from stations where prey species were sampled concomitantly (stations depicted in Fig. 1).

\section{RESULTS}

\section{Hydrographic setting}

For combined 2009 and 2010 data, water temperature and chl a followed the predicted latitudinal trends. Mean upper water column temperatures were significantly warmer in the North, especially along the coast, than in the South, averaging $0.12^{\circ} \mathrm{C}$ and $-0.57^{\circ} \mathrm{C}$, respectively (Fig. $2 \mathrm{~A}, \mathrm{~B}$, Table 1). Integrated chl a (2009 and 2010 combined data) was significantly lower in the North than in the South, averaging $61 \mathrm{mg} \mathrm{m}^{-2}$ and $104 \mathrm{mg} \mathrm{m}^{-2}$, respectively, with maximum values in the southern coastal regions and Marguerite Bay (Table 1).

\section{Prey quality}

\section{Species comparison}

The elemental compositions for the 3 species of krill and Pleuragramma antarcticum were similar, with average $\mathrm{N}$ content ranging from 83.1 to $92.3 \mu \mathrm{g}$ $\mathrm{mg}^{-1}$ DW and average $\mathrm{C}$ content ranging from 415 to $485 \mathrm{\mu g} \mathrm{mg}^{-1} \mathrm{DW}$. Average C:N ratios by mass of Thysanoessa macrura and P. antarcticum (5.5 and 5.7, respectively) were significantly higher compared to Euphausia crystallorophias and total E. superba (4.5 and 4.8, respectively; Table 2 ). The elemental composition of Electrona antarctica was significantly different from all other prey species, with a lower $\mathrm{N}$ content $\left(59.1 \mathrm{\mu g} \mathrm{mg}^{-1} \mathrm{DW}\right)$ and a higher C content $\left(608 \mu \mathrm{g} \mathrm{mg}^{-1} \mathrm{DW}\right)$, resulting in the highest C:N weight ratio (10.3) of all species analyzed (Table 2).

The prey species with the highest overall lipid content was E. antarctica ( $55 \% \mathrm{DW})$, followed by $T$. macrura (45\% DW) and P. antarcticum (39\% DW), although for the latter 2 species, lipid content was statistically indistinguishable. E. crystallorophias and total E. superba had the lowest overall total lipid contents (29\% and $32 \%$ DW, respectively; Table 2). For E. superba, males had significantly lower total lipid $(27 \%$ DW) content than either juveniles (35\% DW) or females (34\% DW; Table 2).

For the measured energy density values, total $E$. superba, P. antarcticum, and E. antarctica were significantly different from each other. E. antarctica had the highest energy density ( $\left.31.9 \mathrm{~kJ} \mathrm{~g}^{-1} \mathrm{DW}\right)$, followed by $P$. antarcticum $\left(24.6 \mathrm{~kJ} \mathrm{~g}^{-1}\right.$ DW) and total $E$. superba (21.1 $\mathrm{kJ} \mathrm{g}^{-1} \mathrm{DW}$; Table 2). Female E. superba energy density was significantly higher $\left(22.0 \mathrm{~kJ} \mathrm{~g}^{-1}\right.$ 
A)

$68^{\circ} \mathrm{W} \quad 62^{\circ} \mathrm{S}$

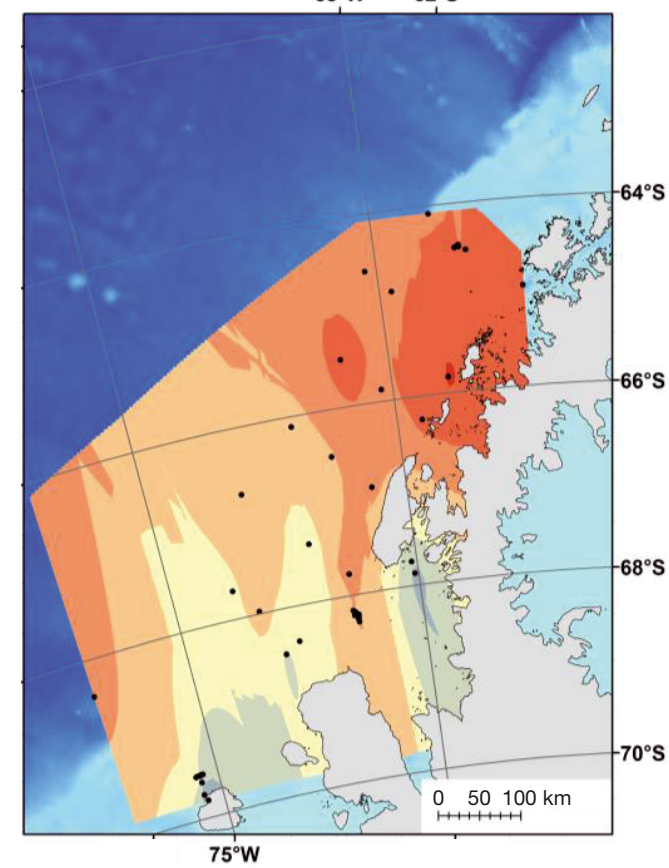

$68^{\circ} \mathrm{W}$

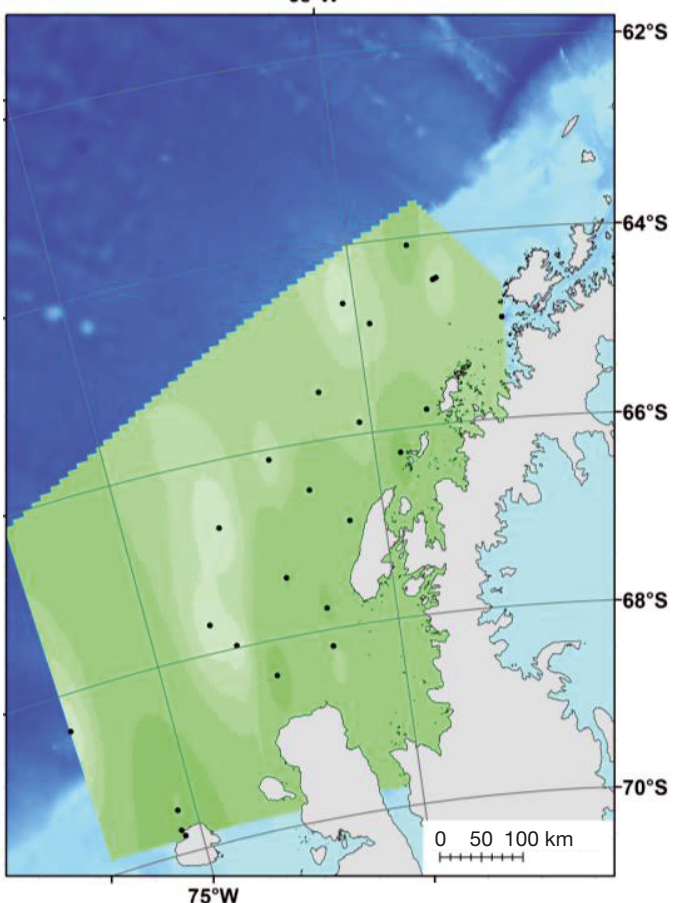

B)

$68^{\circ} \mathrm{W} \quad 62^{\circ} \mathrm{S}$

$120 \mathrm{~m}$ Mean Water Temp $\left({ }^{\circ} \mathrm{C}\right)$
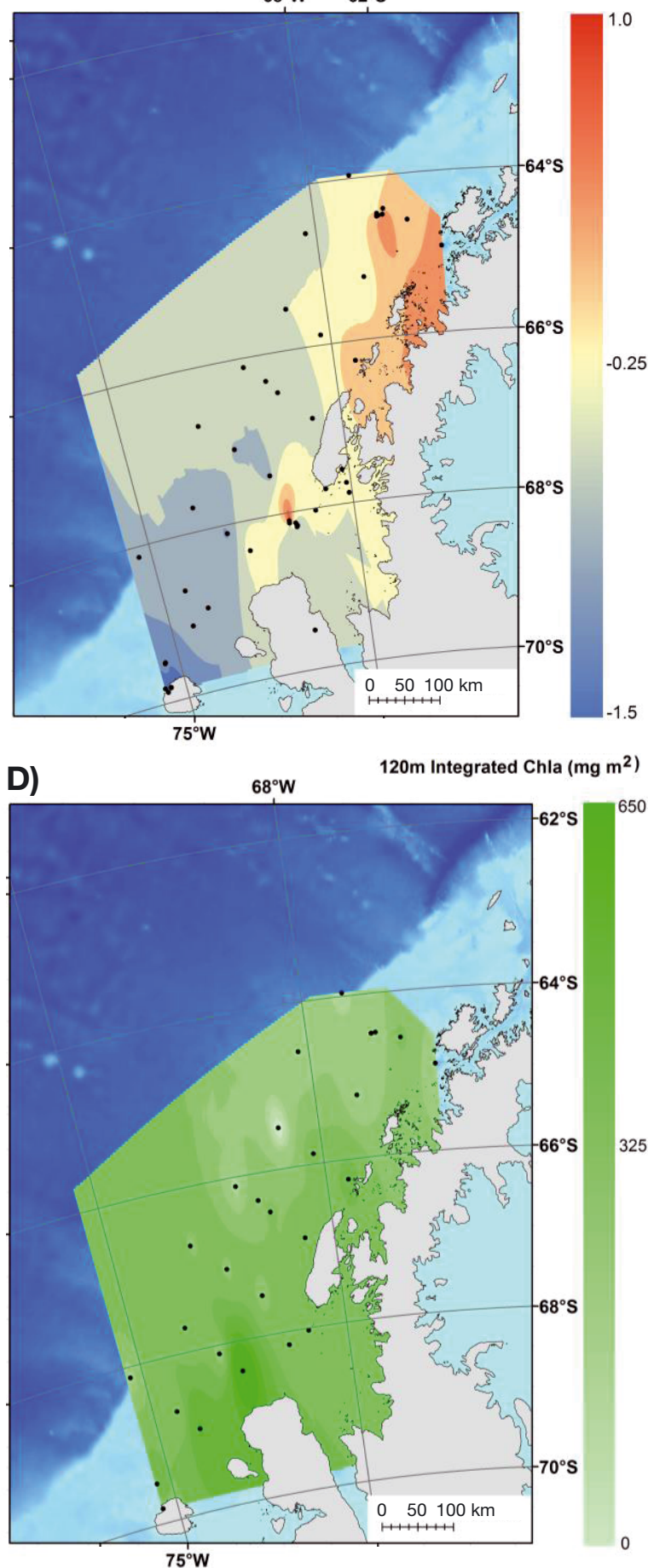

Fig. 2. Regional maps of mean upper water column temperature and integrated chl $a$. (A, B) mean water temperature 0-120 m $\left({ }^{\circ} \mathrm{C}\right)$ and $(\mathrm{C}, \mathrm{D})$ 0-120 $\mathrm{m}$ integrated $\mathrm{chl} \mathrm{a}\left(\mathrm{mg} \mathrm{m}^{-2}\right)$ for the study region from CTD and discrete bottle data collected during the 2009 (A and C) and 2010 (B and D) austral summer cruises in January. Stations occupied are solid, black circles

DW) than male E. superba (19.5 $\mathrm{kJ} \mathrm{g}^{-1} \mathrm{DW}$; Table 2). Using published equations, T. macrura had significantly higher energy densities $\left(28.5 \mathrm{~kJ} \mathrm{~g}^{-1} \mathrm{DW}\right)$ than the other krill species, and E. crystallorophias (21.8 $\left.\mathrm{kJ} \mathrm{g}^{-1} \mathrm{DW}\right)$ was statistically similar to E. superba (Table 2). 
Table 1. Regional comparison of environmental parameters and prey quality. Regional averages (ranges in parentheses) for properties measured in the North and South regions (as defined in Fig. 1), for prey species (euphausiids: Thysanoessa macrura, Euphausia crystallorophias, E. superba; fish: Pleuragramma antarcticum, Electrona antarctica). All regional comparisons are combined 2009 and 2010 data, except for $2011 \mathrm{chl} a, P$. antarcticum, and E. antarctica comparisons, which include 2011 data. Bold type is used to designate significant differences, and p-values are given for all significant results ( $\mathrm{p} \leq 0.05$ ); ns: not significant; DW: dry weight. Dash (-) indicates data from only 1 region and no comparisons were made

\begin{tabular}{|c|c|c|c|c|}
\hline \multicolumn{2}{|c|}{ Property } & North & South & $\mathrm{p}$ \\
\hline \multicolumn{2}{|c|}{ 0-120 m water temperature $\left({ }^{\circ} \mathrm{C}\right)$} & $0.12(-0.60-0.72)$ & $-0.57(-1.69-0.21)$ & $<0.001$ \\
\hline \multicolumn{2}{|c|}{$2009 \& 2010,0-120 \mathrm{~m}$ integrated $\mathrm{chl} a\left(\mathrm{mg} \mathrm{m}^{-2}\right)$} & $60.78(20.45-169.91)$ & $103.82(17.47-623.43)$ & 0.05 \\
\hline \multicolumn{2}{|c|}{$2011,0-120 \mathrm{~m}$ integrated $\mathrm{chl} a\left(\mathrm{mg} \mathrm{m}^{-2}\right)$} & $39.92(10.78-73.70)$ & $255.84(24.41-621.70)$ & $<0.001$ \\
\hline \multirow{5}{*}{$\begin{array}{l}\text { Thysanoessa } \\
\text { macrura }\end{array}$} & Nitrogen $\left(\mu g \mathrm{~N} \mathrm{mg}{ }^{-1} \mathrm{DW}\right)$ & $87(75-118)$ & $79(67-93)$ & ns \\
\hline & Carbon $\left(\mu \mathrm{g} \mathrm{C} \mathrm{mg}{ }^{-1} \mathrm{DW}\right)$ & $432(392-507)$ & $462(419-522)$ & 0.03 \\
\hline & $\mathrm{C}: \mathrm{N}$ ratio & $5.07(3.78-6.25)$ & $5.97(4.56-7.58)$ & 0.04 \\
\hline & Total lipids (\%DW) & $46.22(20.59-71.31)$ & $43.81(22.89-70.40)$ & ns \\
\hline & Total length (mm) & $12.56(10.14-14.87)$ & $14.68(11.62-17.39)$ & 0.01 \\
\hline \multirow{5}{*}{$\begin{array}{l}\text { Euphausia } \\
\text { crystallorophias }\end{array}$} & Nitrogen $\left(\mu g \mathrm{~N} \mathrm{mg}^{-1} \mathrm{DW}\right)$ & $100(96-104)$ & $90(81-100)$ & ns \\
\hline & Carbon $\left(\mu \mathrm{g} \mathrm{C} \mathrm{mg}{ }^{-1} \mathrm{DW}\right)$ & $378(372-382)$ & $424(380-458)$ & ns \\
\hline & $\mathrm{C}: \mathrm{N}$ ratio & $3.77(3.67-3.94)$ & $4.72(3.91-5.16)$ & 0.009 \\
\hline & Total lipids (\%DW) & $19.01(16.96-22.41)$ & $31.66(20.54-42.10)$ & $<0.001$ \\
\hline & Total length (mm) & $28.17(26.83-29.47)$ & 33.09 (30.20-36.38) & 0.003 \\
\hline \multirow{5}{*}{$\begin{array}{l}\text { Juvenile } \\
\text { Euphausia } \\
\text { superba }\end{array}$} & Nitrogen $\left(\mu g \mathrm{~N} \mathrm{mg}^{-1} \mathrm{DW}\right)$ & $83(74-94)$ & $86(72-106)$ & ns \\
\hline & 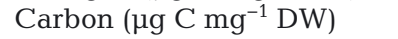 & $413(362-451)$ & $424(390-474)$ & ns \\
\hline & $\mathrm{C}: \mathrm{N}$ ratio & $4.91(3.94-5.72)$ & $4.99(3.92-6.02)$ & ns \\
\hline & Total lipids (\%DW) & $30.96(14.57-48.89)$ & $37.57(21.64-64.51)$ & 0.007 \\
\hline & Total length (mm) & $32.66(27.01-38.87)$ & $32.32(28.08-37.17)$ & ns \\
\hline \multirow{6}{*}{$\begin{array}{l}\text { Male } \\
\text { Euphausia } \\
\text { superba }\end{array}$} & Nitrogen $\left(\mu g \mathrm{~N} \mathrm{mg}^{-1} \mathrm{DW}\right)$ & $93(71-110)$ & $91(71-100)$ & ns \\
\hline & Carbon $\left(\mu \mathrm{g} \mathrm{C} \mathrm{mg}{ }^{-1} \mathrm{DW}\right)$ & $388(316-464)$ & $415(359-503)$ & ns \\
\hline & C:N ratio & $4.20(3.37-5.59)$ & $4.63(3.50-6.39)$ & ns \\
\hline & Total lipids (\%DW) & $24.55(14.06-45.06)$ & $30.54(15.03-54.27)$ & ns \\
\hline & Total length (mm) & $48.63(40.84-52.62)$ & $48.17(43.23-52.53)$ & ns \\
\hline & Energy density (kJ g $\left.{ }^{-1} \mathrm{DW}\right)$ & $19.23(16.02-23.27)$ & $19.84(16.38-24.36)$ & ns \\
\hline \multirow{6}{*}{$\begin{array}{l}\text { Female } \\
\text { Euphausia } \\
\text { superba }\end{array}$} & Nitrogen $\left(\mu \mathrm{g} \mathrm{N} \mathrm{mg}{ }^{-1} \mathrm{DW}\right)$ & $92(83-104)$ & $86(76-97)$ & 0.005 \\
\hline & Carbon $\left(\mu \mathrm{g} \mathrm{C} \mathrm{mg}^{-1} \mathrm{DW}\right)$ & $420(365-454)$ & $433(376-474)$ & ns \\
\hline & $\mathrm{C}: \mathrm{N}$ ratio & $4.60(3.68-5.09)$ & $5.06(4.05-6.21)$ & 0.01 \\
\hline & Total lipids (\%DW) & $30.77(12.46-39.50)$ & $36.26(25.47-54.72)$ & 0.03 \\
\hline & Total length (mm) & $48.18(40.34-51.88)$ & $48.31(43.41-52.60)$ & ns \\
\hline & Energy density ( $\left.\mathrm{kJ} \mathrm{g}^{-1} \mathrm{DW}\right)$ & $21.83(19.00-23.75)$ & $22.13(19.68-25.33)$ & ns \\
\hline \multirow{6}{*}{$\begin{array}{l}\text { Total } \\
\text { Euphausia } \\
\text { superba }\end{array}$} & Nitrogen $\left(\mu g \mathrm{~N} \mathrm{mg}{ }^{-1} \mathrm{DW}\right)$ & $91(71-110)$ & $87(71-106)$ & ns \\
\hline & 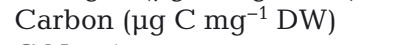 & $405(316-464)$ & $425(359-503)$ & 0.001 \\
\hline & $\mathrm{C}: \mathrm{N}$ ratio & $4.55(3.37-5.72)$ & $4.92(3.50-6.37)$ & 0.004 \\
\hline & Total lipids (\%DW) & $28.51(12.36-48.89)$ & $35.21(15.03-64.51)$ & $<0.001$ \\
\hline & Total length (mm) & $42.61(27.01-52.62)$ & $42.51(28.08-52.60)$ & ns \\
\hline & Energy density ( $\left.\mathrm{kJ} \mathrm{g}^{-1} \mathrm{DW}\right)$ & $20.46(16.02-23.75)$ & $21.45(16.38-25.33)$ & $\mathrm{ns}$ \\
\hline \multirow{6}{*}{$\begin{array}{l}\text { Pleuragramma } \\
\text { antarcticum }\end{array}$} & Nitrogen $\left(\mu g \mathrm{~N} \mathrm{mg}^{-1} \mathrm{DW}\right)$ & & $85(68-98)$ & - \\
\hline & Carbon $\left(\mu \mathrm{g} \mathrm{C} \mathrm{mg}{ }^{-1} \mathrm{DW}\right)$ & & 485 (442-539) & - \\
\hline & $\mathrm{C}: \mathrm{N}$ ratio & & $5.73(4.72-6.97)$ & - \\
\hline & Total lipids (\%DW) & & $38.60(27.41-46.82)$ & - \\
\hline & Standard length (mm) & & $89.93(57.62-116.82)$ & - \\
\hline & Energy density (kJ g $\left.{ }^{-1} \mathrm{DW}\right)$ & & $24.63(22.36-26.93)$ & - \\
\hline \multirow{6}{*}{$\begin{array}{l}\text { Electrona } \\
\text { antarctica }\end{array}$} & Nitrogen $\left(\mu \mathrm{g} \mathrm{N} \mathrm{mg}{ }^{-1} \mathrm{DW}\right)$ & $62(61-64)$ & $58(56-62)$ & 0.05 \\
\hline & 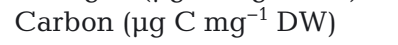 & $592(587-597)$ & $612(555-646)$ & ns \\
\hline & $\mathrm{C}: \mathrm{N}$ ratio & $9.52(9.24-9.80)$ & $10.50(9.49-11.47)$ & ns \\
\hline & Total lipids (\%DW) & $50.60(44.41-56.79)$ & $56.05(50.74-59.82)$ & $\mathrm{ns}$ \\
\hline & Standard length (mm) & $78.87(77.64-80.10)$ & $75.88(54.49-90.09)$ & ns \\
\hline & Energy density ( $\left.\mathrm{kJ} \mathrm{g}^{-1} \mathrm{DW}\right)$ & $31.94(31.82-32.07)$ & $31.92(29.96-32.68)$ & $\mathrm{ns}$ \\
\hline
\end{tabular}




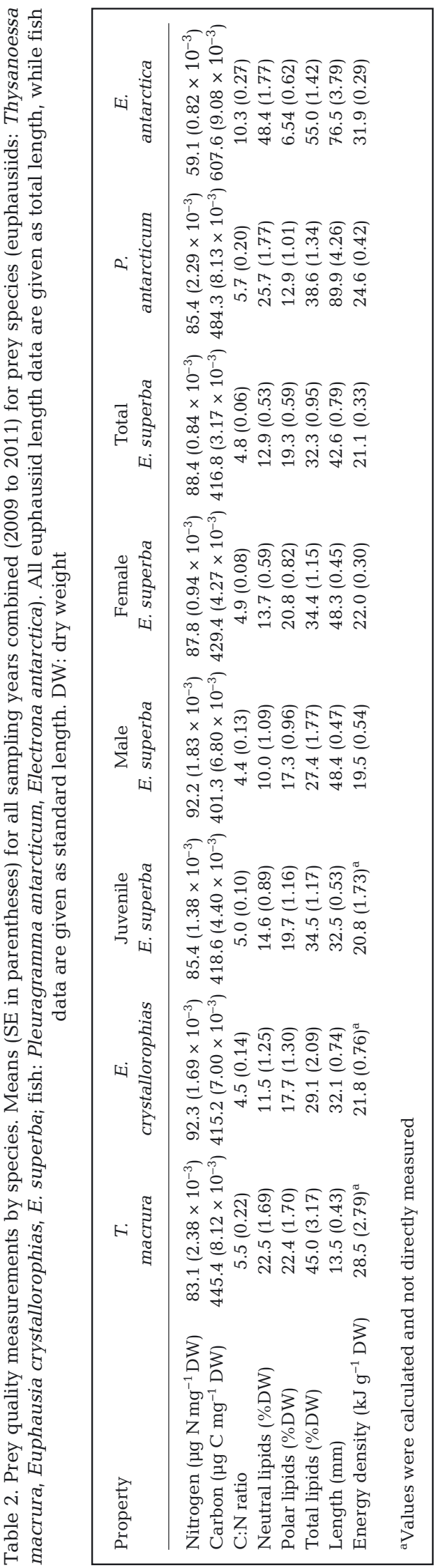

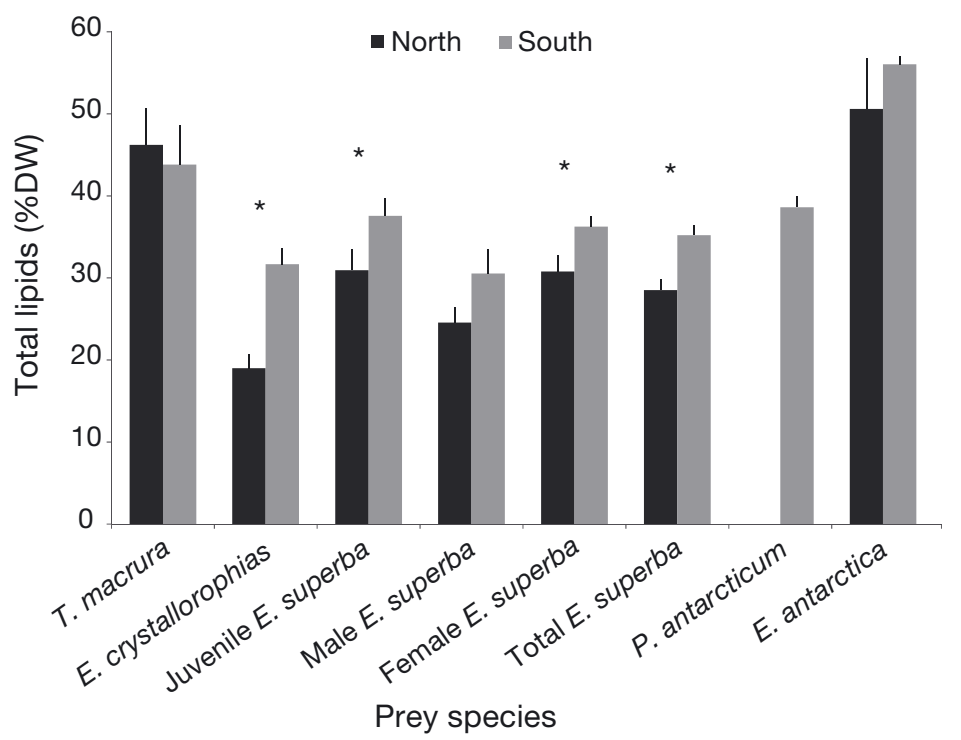

Fig. 3. Average total lipid content (as \% dry weight, DW) in the North and the South regions, for all sampling years (2009-2011), for prey species (euphausiids: Thysanoessa macrura, Euphausia crystallorophias, E. superba; fish: Pleuragramma antarcticum, Electrona antarctica). Error bars are $1 \mathrm{SE}$. Asterisks $\left({ }^{*}\right)$ indicate significant differences in total lipid content between regions. See Table 1 for test statistics

\section{Interannual comparison}

T. macrura and E. crystallorophias exhibited the most interannual variability of the 5 prey species investigated, although these interannual differences can be partially explained by differences in total length of animals sampled in 2009 vs. 2010. There was no significant difference in prey quality of E. superba in January 2009 vs. 2010. Thus for all further analyses, years were combined.

\section{Regional comparison}

Species/life stages for which there were significantly higher total lipid contents in the South (all years combined) included E. crystallorophias, juvenile E. superba, female E. superba, and total E. superba (Fig. 3, Table 1). While not statistically different, E. antarctica and male $E$. superba were generally higher in the South than North. $T$. macrura was the only species analyzed with higher lipid content in the North, although this difference was not significant (Table 1).

North-South differences in total lipid content and C:N values for E. crystallorophias may be partially explained by the higher average individual length of animals collected in the South $(33.1 \mathrm{~mm})$ vs. the North $(28.2 \mathrm{~mm}$; Fig. 3, Table 1). We found a significant, positive relationship between average individual total length vs. total 

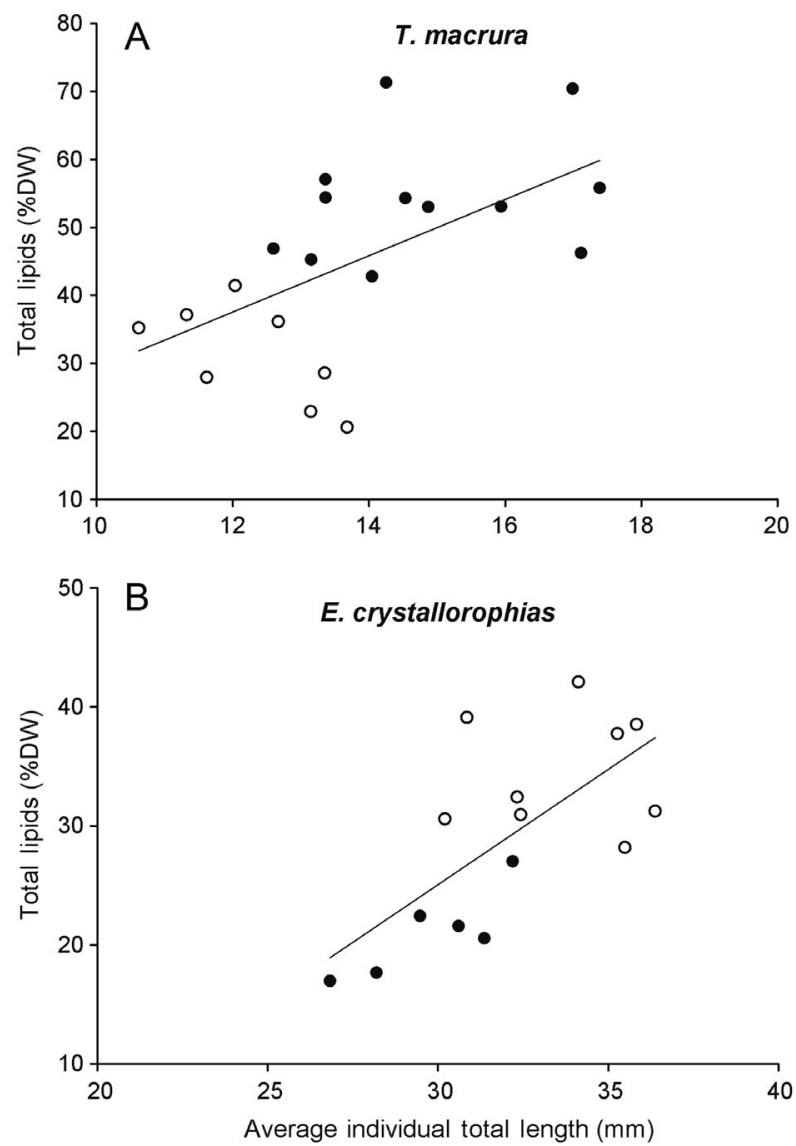

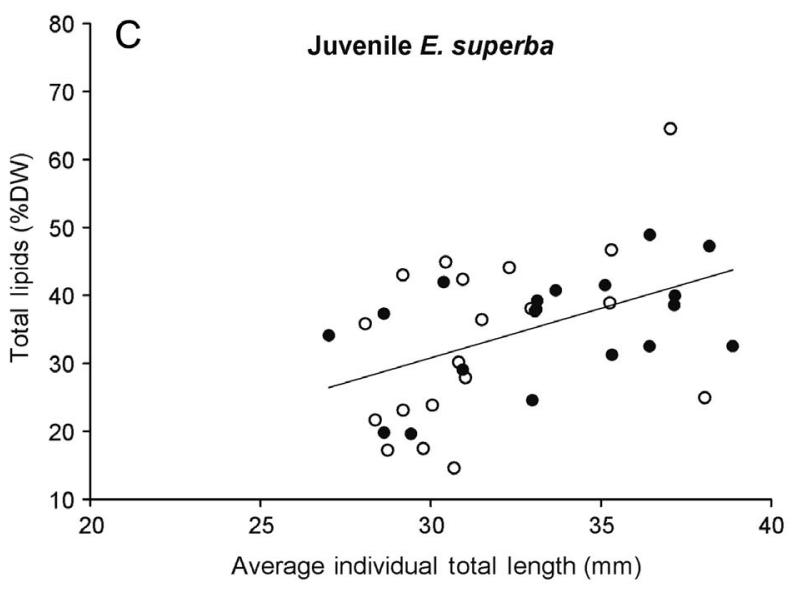

$\bullet 2009$

$\circ 2010$

Fig. 4. Average individual total length (mm) vs. total lipid content (\% dry weight, DW) for the euphausiids (A) Thysanoessa macrura, (B) Euphausia crystallorophias, and (C) juvenile E. superba. Regressions are for combined 2009 and 2010 data. See

Table 3 for regression equations and statistics

Table 3. Relationships between length vs. elemental composition and lipid fraction by species. Average individual length (mm) vs. elemental composition ( $\mu \mathrm{g} \mathrm{N} \mathrm{mg}{ }^{-1}$ dry weight, DW, or $\mu \mathrm{g} \mathrm{C} \mathrm{mg}^{-1} \mathrm{DW}$ ) and lipid fractions (\%DW) for euphausiid prey species: Thysanoessa macrura, Euphausia crystallorophias, juvenile E. superba. No significant length vs. composition relationships were found for other species (not shown). Regression equations are: Elemental Composition $\left(\mu \mathrm{g} \mathrm{N} \mathrm{mg}{ }^{-1} \mathrm{DW}\right.$ or $\mu \mathrm{g} \mathrm{C} \mathrm{mg}{ }^{-1}$ $\mathrm{DW})$ or Lipid Fraction $(\% \mathrm{DW})=m$ (Average Individual Length, $\mathrm{mm})+b . \mathrm{R}^{2}$ values are presented with $\mathrm{p}$-values for all significant relationships (where $\mathrm{p} \leq 0.05$ ); ns, not significant. See also Fig. 4

\begin{tabular}{|c|c|c|c|c|c|c|c|c|c|c|c|}
\hline $\begin{array}{l}\text { Elemental } \\
\text { composition }\end{array}$ & $\begin{array}{l}\text { Slope } \\
(m)\end{array}$ & $\begin{array}{l}\text { Intercept } \\
(b)\end{array}$ & $\mathrm{R}^{2}$ & $\mathrm{p}$ & $\mathrm{n}$ & $\begin{array}{l}\text { Lipid } \\
\text { fraction }\end{array}$ & $\begin{array}{l}\text { Slope } \\
(m)\end{array}$ & $\begin{array}{l}\text { Intercept } \\
\text { (b) }\end{array}$ & $\mathrm{R}^{2}$ & $\mathrm{p}$ & $\mathrm{n}$ \\
\hline \multicolumn{12}{|l|}{ Thysanoessa macrura } \\
\hline Nitrogen $\left(\mu \mathrm{g} \mathrm{N} \mathrm{mg}{ }^{-1} \mathrm{DW}\right)$ & -0.003 & 0.12 & 0.49 & $<0.001$ & 22 & Neutral & 2.87 & -17.18 & 0.52 & 0.0003 & 21 \\
\hline Carbon $\left(\mu \mathrm{g} \mathrm{C} \mathrm{mg}{ }^{-1} \mathrm{DW}\right)$ & 0.01 & 0.28 & 0.35 & 0.006 & 22 & Polar & & & & $0.15, \mathrm{~ns}$ & 22 \\
\hline $\mathrm{C}: \mathrm{N}$ ratio & 0.37 & 0.48 & 0.57 & $<0.001$ & 22 & Total & 4.14 & -12.12 & 0.31 & 0.01 & 21 \\
\hline \multicolumn{12}{|l|}{ Euphausia crystallorophias } \\
\hline Nitrogen $\left(\mu \mathrm{g} \mathrm{N} \mathrm{mg}{ }^{-1} \mathrm{DW}\right)$ & -0.002 & 0.15 & 0.65 & $<0.001$ & 14 & Neutral & 1.13 & -24.74 & 0.45 & 0.006 & 15 \\
\hline Carbon $\left(\mu \mathrm{g} \mathrm{C} \mathrm{mg}{ }^{-1} \mathrm{DW}\right)$ & 0.006 & 0.21 & 0.44 & 0.007 & 14 & Polar & & & & $0.081, \mathrm{~ns}$ & 15 \\
\hline $\mathrm{C}: \mathrm{N}$ ratio & 0.15 & -0.4 & 0.64 & $<0.001$ & 14 & Total & 1.94 & -33.09 & 0.48 & 0.004 & 15 \\
\hline \multicolumn{12}{|l|}{ Juvenile Euphausia superba } \\
\hline Nitrogen $\left(\mu \mathrm{g} \mathrm{N} \mathrm{mg}{ }^{-1} \mathrm{DW}\right)$ & -0.001 & 0.12 & 0.21 & 0.02 & 28 & Neutral & 0.75 & -9.91 & 0.20 & 0.005 & 39 \\
\hline Carbon $\left(\mu \mathrm{g} \mathrm{C} \mathrm{mg}{ }^{-1} \mathrm{DW}\right)$ & & & & $0.08, \mathrm{~ns}$ & 28 & Polar & 0.8 & -6.26 & 0.13 & 0.03 & 39 \\
\hline $\mathrm{C}: \mathrm{N}$ ratio & 0.09 & 2.02 & 0.28 & 0.004 & 28 & Total & 1.46 & -12.97 & 0.21 & 0.004 & 39 \\
\hline
\end{tabular}



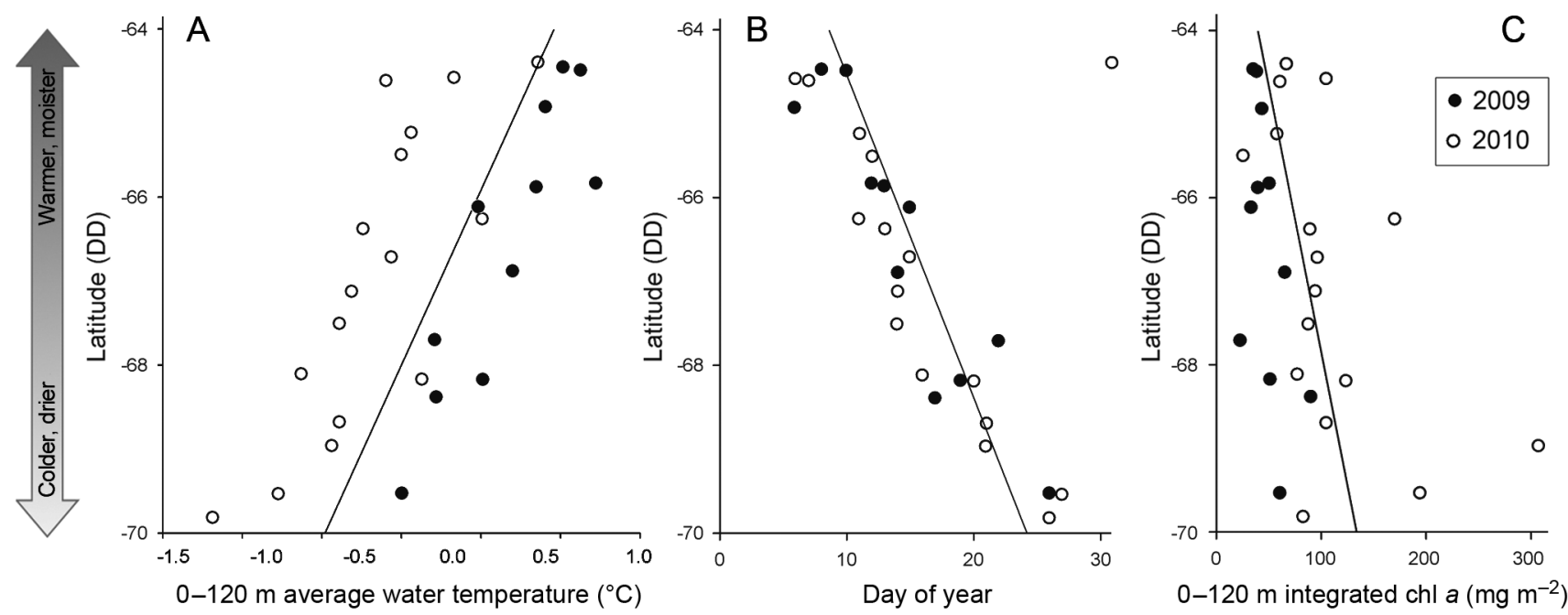

Fig. 5. Relationship between latitude and environmental or temporal parameters. Latitude (decimal degrees, DD) vs. 0-120 m mean water temperature, day of the year, and 0-120 m integrated chl $a$. The $x$ - and $y$-axes in plots have been reversed to better depict the North to South trend. Regressions are for 2009 and 2010 combined data. Regression equations are (Property) = $m$ (Latitude) $+b$, and are all significant $(\mathrm{p}<0.05)$; see Appendix 1 for regression equations and statistics

lipid content, C content, and C:N for T. macrura and E. crystallorophias (Fig. 4, Table 3) as well as a a significant, negative relationship between $\mathrm{N}$ content and average individual total length (Table 3). Thus, the significantly higher total lipid content and C:N values in the South vs. the North for these 2 species are likely due to the larger size of animals in the South (Fig. 3, Table 1). This was confirmed by a reanalysis using both the E. crystallorophias and $T$. macrura data standardized for length, for which we found no significant North-South differences in total lipid content and C:N for either species. Juvenile $E$. superba total lipid content was also significantly positively correlated with length (Fig. 4, Table 3). However, juveniles of various lengths were sampled uniformly across the grid, so the significantly higher total lipid content in the South $(37 \%$ DW) vs. the North $(31 \%$ DW) is more likely due to regional influences on animal physiology (Fig. 3, Table 1).

\section{Relationship with latitude, hydrography, and time}

Latitude, mean upper water column temperature, day of the year sampled, and integrated chl a were all highly correlated with each other due to the structure of the sampling cruise (starting in the north at Anvers Island and ending south at Charcot Island; Figs. 1, 2, \& 5). All relationships between these properties were significant, with the exception of day of the year sampled vs. integrated chl a (see Appendix 1). Latitude was the most important explanatory variable, resulting in the highest $\mathrm{R}^{2}$ values for the relationships between mean upper water column temperature $\left(R^{2}=0.47\right)$, day of the year $\left(R^{2}=0.46\right)$, and integrated chl a $\left(\mathrm{R}^{2}=0.20\right.$; Appendix 1$)$.

Total lipid content for total E. superba (Fig. 6) and for both juvenile and male E. superba (data not shown) increased with increasing latitude south, similar to results for other variables along the North-South gradient as described above. To analyze whether temporal or environmental parameters explained any of these observed trends in variability in E. superba prey quality, we conducted a stepwise multiple linear regression analysis for each prey metric (see 'Materials and methods'). Since some of the variables were highly correlated with each other, we also analyzed interactions between the variables. If variables in the selected model had a correlation coefficient $>0.8$, the variable explaining the least amount of variability was dropped in favor of a simpler model. Combinations of the selected independent variables explained 17 to $34 \%$ of the variability in prey quality metrics (Table 4 ). For the majority of prey metrics analyzed, sex and latitude were consistently important variables. Primary production, sex, and sample year were important explanatory variables in the $\mathrm{C}$ content model, and mean water temperature was important in all lipid models. Lower $\mathrm{N}$ and higher $\mathrm{C}$ and all lipid classes were associated with males, and lower $\mathrm{N}$ and higher lipid content for all lipid classes were associated with higher latitudes. Lipid values were also positively correlated to water temperature after accounting for the influence of latitude. 


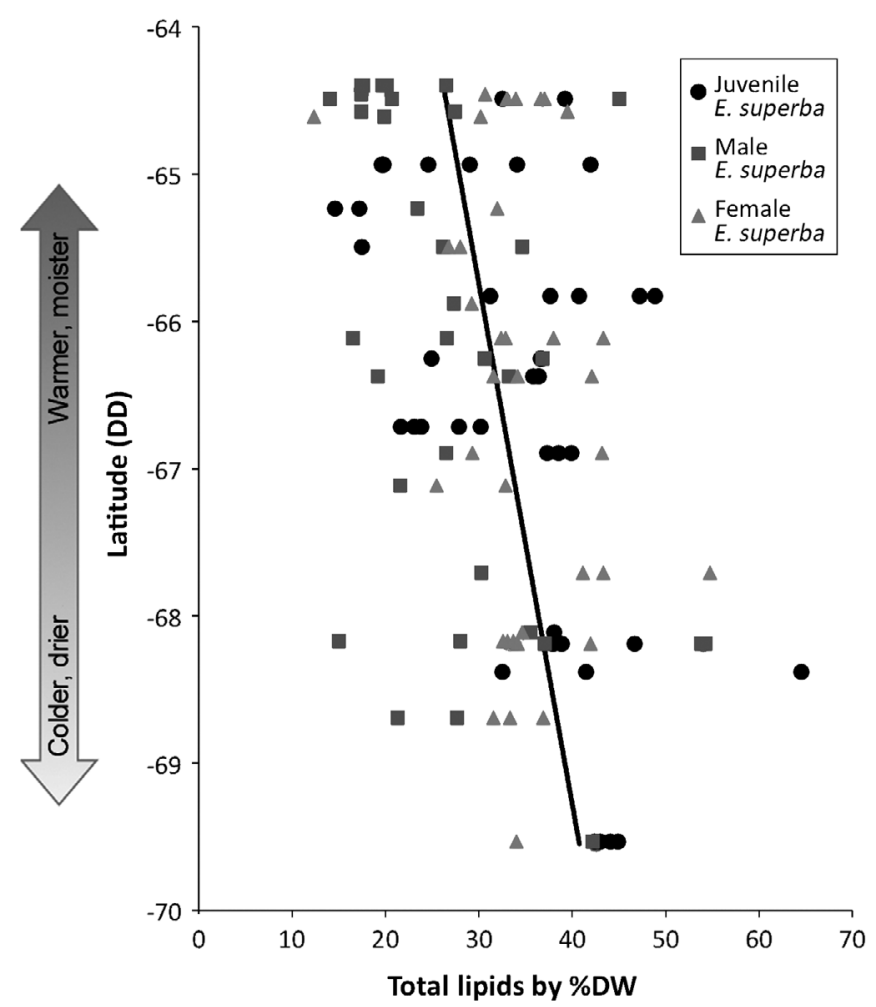

Fig. 6. Latitude (decimal degrees, DD) vs. Euphausia superba total lipid content ( $\%$ dry weight, DW). The $x$ - and $y$-axes in plots have been reversed to better depict the North to South trend. Regressions are for 2009 and 2010 combined data. Regression equations are (Total Lipid Content) $=m$ (Latitude) $+b ; y=2.83 x-156.06, \mathrm{r}^{2}=0.20$. Regression is significant $(p<0.05)$

E. superba lipid content over seasonal progression of summer

Total lipid content was similar for E. superba sampled from the same northern station at the beginning and end of the cruise in 2010 (males, 6 and 31 January, $21.6 \%$ and $20.3 \%$, respectively, p > 0.05) and in 2012 (males, 6 and 30 January, 26.5\% and 30.7\%; juveniles, $31.8 \%$ and $34.3 \%$, respectively, p > 0.05).

\section{DISCUSSION}

\section{Species comparison}

Thysanoessa macrura are the smallest, most abundant euphausiids found throughout the WAP, concentrated around the northern continental shelf /slope intersection (Nordhausen 1992, Ross et al. 2008). While T. macrura are found in stomach contents of Adélie penguins along the WAP, they are usually overlooked as a potentially valuable prey item (Ross et al. 2008). T. macrura had higher total lipid content by \% dry weight than the other krill species analyzed in our study, and were statistically similar to the fish Pleuragramma antarcticum (although our T. macrura total lipid values were generally higher than previously reported for this species; our Table 2, Falk-Petersen et al. 2000, Färber-Lorda \& Mayzaud 2010), thus T. macrura has potential to be a high-quality food item for penguins. The 2 other species of krill, Euphausia superba and E. crystallorophias, are well-recognized and well-studied prey items for whales, penguins, and seals (Ross et al. 2008, Chapman et al. 2010, Friedlaender et al. 2011). Total lipid contents for these 2 species were statistically similar, and they were the only species sampled with higher polar than neutral lipid content.

E. superba total lipid content as \%DW in our study was roughly $50 \%$ higher than that reported by Färber-Lorda et al. (2009) in summer in the southern sector of the Indian Ocean, and by Clarke (1980) and Torres et al. (1994) in summer and fall, respectively, in the Scotia Sea. Hagen et al. (1996) reported very similar values to ours in summer in the Weddell Sea, and Atkinson et al. (2002) measured values 30\% higher than ours from autumn in the Lazarev Sea. This variability amongst studies highlights the importance of considering season and region when estimating krill lipid content.

$P$. antarcticum had higher total lipid content than $E$. crystallorophias and E. superba, and higher relative neutral lipid content than any of the 3 krill species sampled (Table 2). P. antarcticum were historically a consistent prey item for Adélie penguins along the WAP, but range contractions coincident with regional warming have now restricted their abundances to waters south of Adelaide Island (Fig. 1) (Emslie \& Patterson 2007, W. Fraser pers. comm.). When available, Adélie penguins most frequently take fish 95 to $120 \mathrm{~mm}$ in standard length, corresponding to year-3 and year-4 age classes (McDaniel \& Emslie 2002, Ainley et al. 2003, Chapman et al. 2011). The standard length of fish sampled in the present study ranged from 57.6 to $116.8 \mathrm{~mm}$, with an average of $89.9 \mathrm{~mm}$, representing fish from age classes 2, 3, and $4+$ (Hubold \& Tomo 1989, Chapman et al. 2011). Few biochemical data are available for these older age classes (Chapman et al. 2011). We thus added our lipid data to the model of Chapman et al. (2011); our samples, which include year-3 and year-4 age classes not previously incorporated, fit well within their model with the exception of our 2010 data (Fig. 7). This deviation in 2010 may have been due to a fish diet deficiency, as Pinkerton et al. (2013) showed that 
Table 4. Explanatory variables and statistical scores obtained from the best model among stepwise multiple regression analyses of various biochemical properties of Euphausia superba. Variables included in the best model for elemental composition ( $\mu \mathrm{g} \mathrm{N} \mathrm{mg}{ }^{-1}$ dry weight, DW, or $\mu \mathrm{g} \mathrm{C} \mathrm{mg}^{-1} \mathrm{DW}$ ) and lipid fractions (\%DW) for all combined E. superba data. Latitude is the absolute value of the decimal degree (DD). ' $n$ ' defines the number of data points used to create the model. Test statistics include $\mathrm{R}^{2}$ and $\mathrm{p}$-values for the overall model (in parentheses) and the coefficient for the regression equation, the standard error (SE) associated with the model coefficient, the $t$-value, and the 2 tailed p-value used in testing the null hypothesis for each significant model variable

\begin{tabular}{|c|c|c|c|c|}
\hline Variable & Coefficient & SE & $t$ & $\mathrm{p}$ \\
\hline \multicolumn{5}{|l|}{ Nitrogen $\left(\mu \mathrm{g} \mathrm{N} \mathrm{mg}{ }^{-1} \mathrm{DW}\right)\left(\mathrm{R}^{2}=0.17, \mathrm{p}<0.001, \mathrm{n}=99\right)$} \\
\hline Intercept & 0.192 & 0.035 & 5.57 & $<0.001$ \\
\hline Male & 0.005 & 0.002 & 2.82 & 0.006 \\
\hline Latitude (DD) & -0.002 & 0.001 & 3.06 & 0.003 \\
\hline \multicolumn{5}{|l|}{ Carbon $\left(\mu \mathrm{g} \mathrm{C} \mathrm{mg}{ }^{-1} \mathrm{DW}\right)\left(\mathrm{R}^{2}=0.27, \mathrm{p}<0.001, \mathrm{n}=95\right)$} \\
\hline Intercept & 0.466 & 0.105 & 44.27 & $<0.001$ \\
\hline Male & -0.016 & 0.006 & -2.57 & 0.012 \\
\hline $0-120 \mathrm{~m}$ integrated primary production $\left(\mathrm{mg} \mathrm{m}^{-2} \mathrm{~d}^{-1}\right)$ & $3.85 \times 10^{-6}$ & $1.07 \times 10^{-6}$ & 3.58 & 0.001 \\
\hline Year & 0.038 & 0.008 & 4.62 & $<0.001$ \\
\hline \multicolumn{5}{|l|}{ Neutral lipids (\%DW) $\left(\mathrm{R}^{2}=0.29, \mathrm{p}<0.001, \mathrm{n}=109\right)$} \\
\hline Intercept & -114.507 & 25.141 & 4.55 & $<0.001$ \\
\hline Male & -3.485 & 0.991 & 3.52 & 0.001 \\
\hline Latitude (DD) & 1.941 & 0.379 & 5.12 & $<0.001$ \\
\hline $0-120 \mathrm{~m}$ mean water temperature $\left({ }^{\circ} \mathrm{C}\right)$ & 3.267 & 1.073 & 3.04 & 0.003 \\
\hline \multicolumn{5}{|l|}{ Polar lipids (\%DW) $\left(\mathrm{R}^{2}=0.21, \mathrm{p}<0.001, \mathrm{n}=109\right)$} \\
\hline Intercept & -110.235 & 29.411 & 3.75 & $<0.001$ \\
\hline Male & -2.214 & 1.159 & 1.91 & 0.059 \\
\hline Latitude (DD) & 1.966 & 0.444 & 4.43 & $<0.001$ \\
\hline $0-120 \mathrm{~m}$ mean water temperature $\left({ }^{\circ} \mathrm{C}\right)$ & 2.410 & 1.255 & 1.92 & 0.058 \\
\hline \multicolumn{5}{|l|}{ Total lipids $(\% \mathrm{DW})\left(\mathrm{R}^{2}=0.34, \mathrm{p}<0.001, \mathrm{n}=109\right)$} \\
\hline Intercept & -222.776 & 43.056 & 5.17 & $<0.001$ \\
\hline Male & -5.808 & 1.697 & 3.42 & 0.002 \\
\hline Latitude (DD) & 3.878 & 0.650 & 5.97 & $<0.001$ \\
\hline 0-120 m mean water temperature $\left({ }^{\circ} \mathrm{C}\right)$ & 5.757 & 1.838 & 3.13 & 0.002 \\
\hline
\end{tabular}

postlarval $P$. antarcticum (50-89 mm standard length) exclusively consumed copepods, and 2010 was a year of anomalously low copepod abundances in the WAP (M. Gleiber et al. unpublished data).

Electrona antarctica is a numerically dominant, oceanic species of myctophid mainly found near the continental shelf/slope interface of the WAP (Donnelly \& Torres 2008). These myctophids also access shelf and coastal regions through intrusions of warm, UCDW water and are present in both the northern and southern WAP (Donnelly \& Torres 2008). Their exceptionally high lipid content, dominated by the neutral lipid fraction, resulted in the highest overall energy density. They are important in the diets of higher predators such as Weddell, crabeater, and Antarctic fur seals and various marine birds (Hopkins et al. 1993, Casaux et al. 2011, Hückstädt et al. 2012), and their occurrence in northern, coastal regions of the WAP makes $E$. antarctica an energy-rich option for predators residing near Anvers Island, where $P$. antarcticum no longer persists (McDaniel \& Emslie 2002).
The high lipid content of T. macrura and E. antarctica may suggest high prey quality, but this conclusion is somewhat tempered by the high percentage of neutral lipids in these species, components of which may be less easily assimilated. Previous studies have shown that the neutral lipids in both of these species are mainly composed of wax esters (Hagen \& Kattner 1998, Connan et al. 2010), rather than the triglycerides that dominate the neutral lipid classes of $E$. superba and P. antarcticum (Wöhrmann et al. 1997, Ju et al. 2009). Some penguin species have roughly $20 \%$ lower assimilation efficiency for wax esters relative to triglycerides, detracting from the overall prey quality for species that store wax esters in high concentrations (Jackson \& Place 1990).

\section{Regional comparisons of prey quality}

The North is characterized by a variable, but lengthy, season of low sea-ice concentration, while the South's sea-ice season is longer (Dierssen et al. 


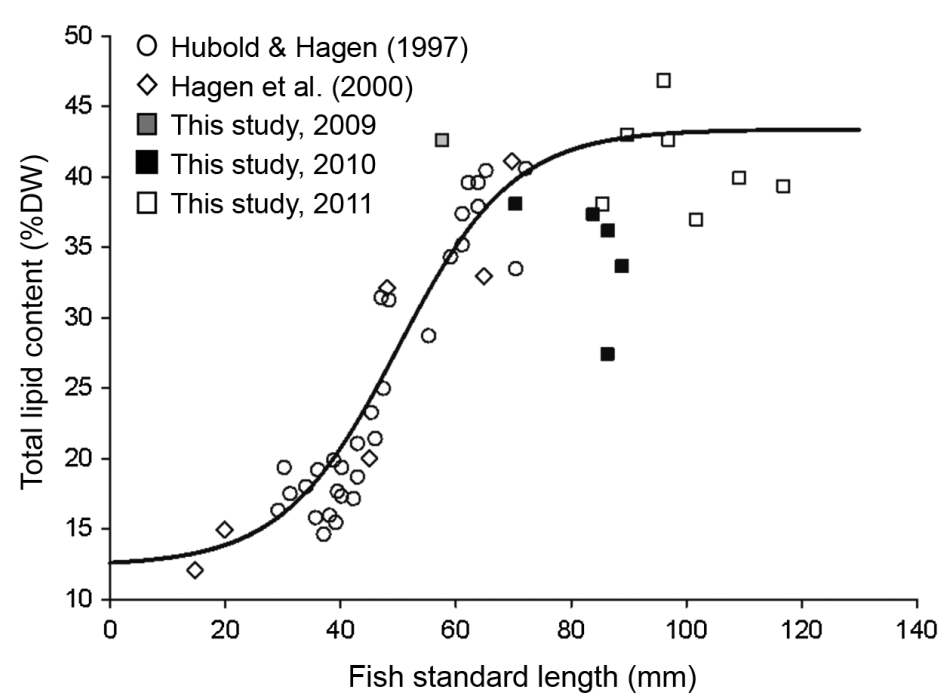

Fig. 7. Individual standard length ( $\mathrm{mm}$ ) vs. total lipid content (\% dry weight, DW) for the fish Pleuragramma antarcticum (adapted from Chapman et al. 2011). The formula for the energy density function is: $\operatorname{Lip}(L)=\left[\left(\operatorname{Lip}_{\max }-\operatorname{Lip}_{\min }\right) \times 1 /\left(1+\mathrm{e}^{-\mathrm{klip}(L-\mathrm{klip} 50)}\right)\right]+\operatorname{Lip}_{\min }$, where $\operatorname{Lip}(L)=$ lipid content of fish with total length $L(\mathrm{~mm}) ; \operatorname{Lip}_{\max }=$ maximum lipid content (as proportion dry mass) ${ }_{i} \operatorname{Lip}_{\min }=$ minimum lipid content (proportion dry mass); $\mathrm{k}_{\text {lip }}$ controls the rate of increase in lipid content with increasing $L$ (set to $0.1 \mathrm{~mm}^{-1}$ ); and $\mathrm{k}_{\text {lip50 }}=L$ at which the lipid content is $50 \%$ of its maximum value (set to $50 \mathrm{~mm}$ )

2002, Stammerjohn et al. 2008). In our study, summer sea ice was present in the far southern portion of the WAP during each sampling year. Another feature of the South is a persistent, cyclonic gyre located on the shelf off Marguerite Bay that has been hypothesized to retain phytoplankton and larval krill (Klinck et al. 2004, Wiebe et al. 2011). Marguerite Bay has also been recognized as a biological hot spot of enhanced productivity with high chl a (Vernet et al. 2008), macro- and microzooplankton biomass (Marrari et al. 2011, Garzio \& Steinberg 2013), and apex predators (Friedlaender et al. 2011).

Regional differences in prey quality for the combined 2009 and 2010 juvenile, female, and total E. superba suggest that some confluence of environmental factors improve habitat in the South and increase the prey quality of krill. The physiological response of organisms to climate change is usually thought of as secondary in importance to broad, ecosystem-based trends, but polar invertebrates and ectotherms, whose metabolic rates vary with the ambient environment, have narrow temperature tolerances, which may prove important as the WAP region continues to warm (Peck et al. 2004, Ducklow et al. 2012, Flores et al. 2012). The changing food base in the WAP could also affect E. superba physiology. Along with the previously discussed reduction

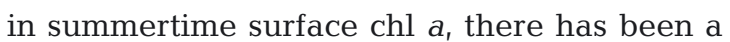
restructuring of the phytoplankton community, where cells $>20 \mu \mathrm{m}$ are more prevalent in the South, and smaller-celled organisms such as flagellates are becoming more prevalent in the far North (Montes-Hugo et al. 2009). E. superba preferentially feed on diatoms and have significantly lower grazing efficiencies when particles are $<20 \mu \mathrm{m}$ (McClatchie \& Boyd 1983, Haberman et al. 2003). Declines in diatoms, a preferred food source, could affect the ability of krill to accumulate lipid stores in preparation for winter. This hypothesis is consistent with the significantly higher total lipid content in the South for juvenile, female, and total E. superba groups (with male E. superba and the fish $E$. antarctica exhibiting the same general trend). The overall decline in diatom abundance in the North also has implications for E. superba winter survival and feeding ecology. Diatoms from the summer phytoplankton bloom aggregate and sink out of surface waters, providing a strong seasonal pulse of labile organic carbon to the benthos (Smith et al. 2008). E. superba access benthic habitats year-round (including abyssal plains as deep as $3500 \mathrm{~m}$ ) and utilize phytodetritus as an alternate food source (Clarke \& Tyler 2008, Schmidt et al. 2011, 2013, Flores et al. 2012). The importance, frequency, and seasonality of krill benthic feeding is still not well understood, but decreasing diatom biomass in the northern WAP would equate to a lower particulate organic carbon flux to the benthos, potentially resulting in lower overall food availability for krill during winter months.

\section{Relationship of prey quality with latitude and hydrography}

Results from our stepwise multiple regression analyses for E. superba showed that sexual differences and latitude were most important in explaining the variability in modeled prey metrics (Table 4). Sexual differences in E. superba lipid and $C_{1} N$ content similar to those observed in our study (Table 2) have been described previously (Clarke 1980, Färber-Lorda et al. 2009) and explained more of the variability in $E$. superba prey metrics than any of the temporal or environmental variables tested. Males expend much of their energy on high growth rates (presumably to increase reproductive success), resulting in a much lower lipid content and a higher mortality, which in turn makes their biochemical composition markedly 
different from juveniles and mature females (Clarke 1980, Kawaguchi et al. 2007, Färber-Lorda et al. 2009). Thus geographic differences in sex ratios could have an effect on predator nutrition, highlighting the importance of including sexual differentiation in any energetics or food web study of E. superba.

Integrated primary production was also an important explanatory variable for E. superba carbon content, with carbon content increasing as primary production increased (Table 4). It is interesting then that primary production was not also an important explanatory variable for E. superba lipid content, because carbon is the main element from which lipid molecules are constructed (Ventura 2006). Perhaps instead of using the surplus food to produce lipid stores, that energy is shunted towards other compounds such as proteins, amino acids, carbohydrates, chitin, or RNA, which could explain the results of our carbon model.

Latitude was the next most important explanatory variable across the majority of the prey metrics analyzed, with $\mathrm{N}$ content decreasing with increasing latitude, and neutral, polar, and total lipid content increasing with increasing latitude (Table 4). The N relationship with latitude is driven by lipid variability because variations in $\mathrm{N}$ content were best explained by the animal's neutral lipid content (Fig. 8). Based on previous studies, the neutral lipid fractions of $E$. superba are mainly composed of triglycerides (Hagen et al. 1996, Ju et al. 2009). Triglycerides are comprised of 3 fatty acids bonded to a glycerol backbone through ester bonds and are composed of $77 \% \mathrm{C}$ and $0 \%$ N (Ventura 2006). Proteins, free amino acids, RNA, DNA, chitin, and phospholipids contribute to the overall N content of krill (Ventura 2006). Thus, as E. superba retained higher concentrations of neutral lipids, the overall contribution of the lipids to the dry weight increased, decreasing the overall $\mathrm{N}$ content of the animal (Fig. 8).

While less important than sex and latitude, temperature was also an explanatory variable included in all lipid class models for E. superba (Table 4), with warmer water temperatures resulting in higher lipid content. This appears contrary to results discussed above showing that lipid content was higher in the (colder) South. However, we posit that this relationship may be explained by presence of more highly productive inshore stations in the South. A number of the inshore stations were warmer and more productive than their offshore counterparts on the same or more northerly sampling lines (Fig. 2). For example, in 2010, the 0-120 m mean temperature for an offshore station in the far northern section of the sam-

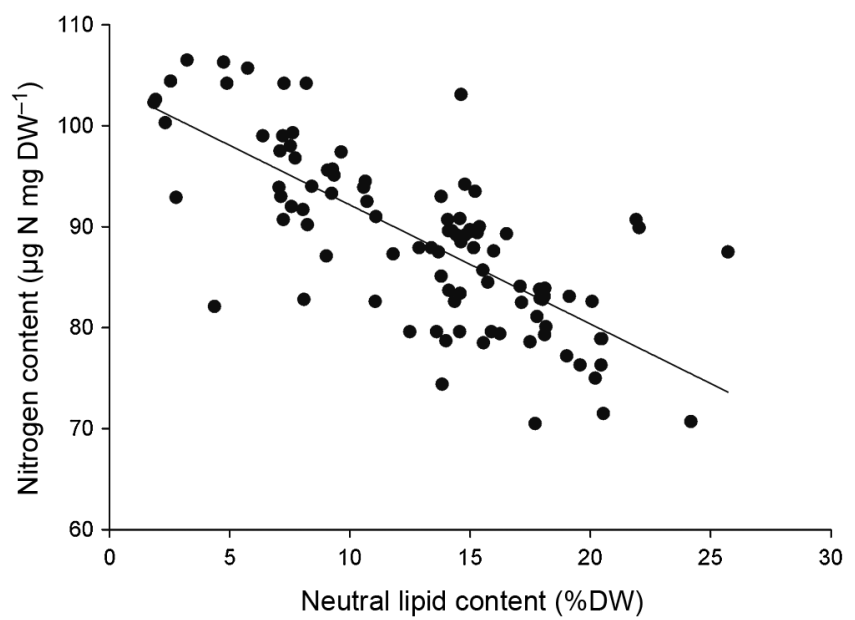

Fig. 8. Relationship between neutral lipid content and nitrogen content for Euphausia superba. Regression equations: $y$

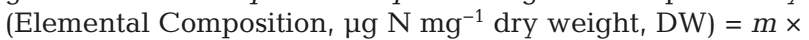
$x($ Neutral Lipid Content, \%DW $)+b ; y=-0012 x+0.104, \mathrm{r}^{2}=$ 0.54 . Regressions are for combined 2009 and 2010 data and all are significant $(\mathrm{p} \leq 0.05)$

pling region was $0.2^{\circ} \mathrm{C}$ cooler than an inshore station located only $200 \mathrm{~km}$ to the south. The inshore stations are in general more productive as well, and perhaps better habitat for krill. A recent study by Garzio \& Steinberg (2013) in the WAP showed that microzooplankton biomass was also higher inshore vs. offshore. Thus, higher phytoplankton and microzooplankton prey availability for E. superba in more productive, and sometimes warmer, inshore waters in the south may lead to higher lipid content of E. superba.

\section{CONCLUSION}

Rapid regional warming in the WAP ecosystem is fundamentally altering ecosystem structure, and if the trends continue, the northern WAP will soon be characterized by a lack of perennial or summer sea ice, lower phytoplankton biomass, and phytoplankton dominated by smaller cells as opposed to diatoms (Martinson et al. 2008, Stammerjohn et al. 2008, Montes-Hugo et al. 2009). We found a confluence of environmental factors that affect prey quality in the WAP, leading to significantly higher Euphausia superba total lipid content across all sexes and maturity stages in the South than in the North. Our model also indicated latitude as a significant variable in predicting E. superba nitrogen and lipid content, and that southern, inshore, more productive stations are likely favorable for krill lipid accumulation. These regional differences could have ramifications for the 
rich assemblage of apex predators that summer in the WAP, and suggests that northern apex predators may have to consume more prey to meet their energetic demands or increase their reliance on other prey sources. The krill E. crystallorophias and fish Pleuragramma antarcticum are also high-quality prey, but their ranges are largely restricted to the South, where summer sea ice still persists. The myctophid Electrona antarctica represents a potential, energyrich option for coastal marine predators residing in the North, but its reliance on intrusions of UCDW for transport across the shelf raises questions on how often this prey item is reliably available. Incorporating these species-specific prey quality dynamics into future energetics modeling efforts focused on the WAP will increase model accuracy by improving the quality of functions regulating predator growth.

Acknowledgements. We thank the Captain, officers, and crew of the ARSV 'Laurence M. Gould' and Raytheon Polar Services scientific support personnel for their logistical support during the Palmer LTER cruises. We thank Erin Ferer, Paul Littreal, and Matt Mainor for their help with the lipid analyses; Jenny Dryer for help with CHN analysis; Ryan Schlosser for assistance with the bomb calorimeter; and Bill Fraser and Sharon Stammerjohn for providing unpublished sea ice and penguin diet data. Joe Cope provided help with the data analyses. Rodger Harvey and Walker Smith provided helpful feedback on an early draft of the manuscript. This study was funded by the National Science Foundation Office of Polar Programs (OPP-0823101). Additional funding to support K.E.R.'s participation on a Palmer LTER cruise was provided by Adrian G. 'Casey' Duplantier Jr. and the 1st Advantage Federal Credit Union of Newport News, Virginia, USA. This is contribution number 3390 from the Virginia Institute of Marine Science.

\section{LITERATURE CITED}

Ainley DG, Wilson PR, Barton KJ, Ballard G, Nur N, Karl B (1998) Diet and foraging effort of Adélie Penguins in relation to pack-ice conditions in the southern Ross Sea. Polar Biol 20:311-319

Ainley DG, Ballard G, Barton KJ, Karl BJ, Rau GH, Ribic CA, Wilson PR (2003) Spatial and temporal variation of diet within a presumed metapopulation of Adélie penguins. Condor 105:95-105

Atkinson A, Meyer B, Stübing D, Hagen W, Schmidt K, Bathmann UV (2002) Feeding and energy budgets of Antarctic krill Euphausia superba at the onset of winter. II. Juveniles and adults. Limnol Oceanogr 47:953-966

Bernard KS, Steinberg DK, Schofield OME (2012) Summertime grazing impact of the dominant macrozooplankton off the Western Antarctic Peninsula. Deep-Sea Res I 62: $111-122$

Casaux R, Bertolin ML, Carlini A (2011) Feeding habits of three seal species at the Danco Coast, Antarctica: a reassessment. Polar Biol 34:1615-1620

Chapman EW, Hofmann EE, Petterson DL, Fraser WR (2010)
The effects of variability in Antarctic krill (Euphausia superba) spawning behavior and sex/maturity stage distribution on Adélie penguin (Pygoscelis adeliae) chick growth: a modeling study. Deep-Sea Res II 57:543-558

Chapman EW, Hofmann EE, Patterson DL, Ribic CA, Fraser WR (2011) Marine and terrestrial factors affecting Adélie penguin Pygoscelis adeliae chick growth and recruitment off the Western Antarctic Peninsula. Mar Ecol Prog Ser 436:273-289

Clarke A (1980) The biochemical composition of krill, Euphausia superba Dana, from South Georgia. J Exp Mar Biol Ecol 43:221-236

Clarke A, Tyler PA (2008) Adult Antarctic krill feeding at abyssal depths. Curr Biol 18:282-285

- Connan M, Mayzaud P, Duhamel G, Bonnevie BT, Cherel Y (2010) Fatty acid signature analysis documents the diet of five myctophid fish from the Southern Ocean. Mar Biol 157:2303-2316

Costa DP, Crocker DE (1996) Marine mammals of the Southern Ocean. In: Ross RM, Hofmann EE, Quetin LB (eds) Foundations for ecological research west of the Antarctic Peninsula. American Geophysical Union, Washington, DC, p 287-301

Dierssen HM, Smith RC, Vernet M (2002) Glacial meltwater dynamics in coastal waters west of the Antarctic Peninsula. Proc Natl Acad Sci USA 99:1790-1795

> Dinniman MS, Klinck JM, Hofmann EE (2012) Sensitivity of circumpolar deep water transport and ice shelf basal melt along the West Antarctic Peninsula to changes in the winds. J Clim 25:4799-4816

Donnelly J, Torres JJ (2008) Pelagic fishes in the Marguerite Bay region of the West Antarctic Peninsula continental shelf. Deep-Sea Res II 55:523-539

Ducklow H, Clarke A, Dickhut R, Doney SC and others (2012) The marine system of the Western Antarctic Peninsula. In: Rogers AD, Johnston NM, Murphy EJ, Clarke A (eds) Antarctic ecosystems: an extreme environment in a changing world. Blackwell, London, p 121-159

Emslie SD, Patterson WP (2007) Abrupt recent shift in $\delta^{13} \mathrm{C}$ and $\delta^{15} \mathrm{~N}$ values in Adélie penguin eggshell in Antarctica. Proc Natl Acad Sci USA 104:11666-11669

> Falk-Petersen S, Hagen W, Kattner G, Clarke A, Sargent J (2000) Lipids, trophic relationships, and biodiversity in Arctic and Antarctic krill. Can J Fish Aquat Sci 57:178-191

> Färber-Lorda J (1994) Length vs. weight relationships and coefficient of condition of Euphausia superba and Thysanoessa macrura of the SW Indian Ocean during summer. Mar Biol 118:645-650

Färber-Lorda J, Mayzaud P (2010) Morphology and total lipids in Thysanoessa macrura from the southern part of the Indian Ocean during summer. Spatial and sex differences. Deep-Sea Res II 57:565-571

> Färber-Lorda J, Gaudy R, Mayzaud P (2009) Elemental composition, biochemical composition and caloric value of Antarctic krill. Implications in energetics and carbon balances. J Mar Syst 78:518-524

Flores H, Atkinson A, Kawaguchi S, Krafft BA and others (2012) Impact of climate change on Antarctic krill. Mar Ecol Prog Ser 458:1-19

Fraser WR, Trivelpiece WZ (1996) Factors controlling the distribution of seabirds: winter-summer heterogeneity in the distribution of Adelie penguin populations. In: Ross RM, Hofmann EE, Quetin LB (eds) Foundations for ecological research west of the Antarctic Peninsula, Vol 70. American Geophysical Union, Washington, DC, p 257-272 
Fraser WR, Patterson-Fraser DL, Ribic CA, Schofield O, Ducklow H (2013) A nonmarine source of variability in Adélie penguin demography. Oceanography 26:207-209

Friedlaender AS, Johnston DW, Fraser WR, Burns J, Halpin PN, Costa DP (2011) Ecological niche modeling of sympatric krill predators around Marguerite Bay, Western Antarctic Peninsula. Deep-Sea Res II 58:1729-1740

- Garzio LM, Steinberg DK (2013) Microzooplankton community composition along the Western Antarctic Peninsula. Deep-Sea Res I 77:36-49

Golet GH, Kuletz KJ, Roby DD, Irons DB (2000) Adult prey choice affects chick growth and reproductive success in pigeon guillemots. Auk 117:82-91

Haberman KL, Ross RM, Quetin LB (2003) Diet of the Antarctic krill (Euphausia superba Dana): II. Selective grazing on mixed phytoplankton assemblages. J Exp Mar Biol Ecol 283:97-113

Hagen W, Kattner V (1998) Lipid metabolism of the Antarctic euphausiid Thysanoessa macrura and its ecological implication. Limnol Oceanogr 43:1894-1901

> Hagen W, Van Vleet ES, Kattner G (1996) Seasonal lipid storage as overwintering strategy of Antarctic krill. Mar Ecol Prog Ser 134:85-89

Hagen W, Kattner G, Friedrich C (2000) The lipid composition of high-Antarctic notothenioid fish species with different life strategies. Polar Biol 23:785-791

Hofmann EE, Klinck JM, Lascara CM, Smith DA (1996) Water mass distribution and circulation west of the Antarctic Peninsula and including Bransfield Strait. In: Ross RM, Hofmann EE, Quetin LB (eds) Foundations for ecological research west of the Antarctic Peninsula, Vol 70. American Geophysical Union, Washington, DC, p 61-80

> Hopkins TC, Ainley DG, Torres JJ, Lancraft TM (1993) Trophic structure in open waters of the marginal ice zone in the Scotia-Weddell confluence region during spring (1983). Polar Biol 13:389-397

Hubold G, Hagen W (1997) Seasonality of feeding and lipid content in juvenile Pleuragramma antarcticum (Pisces: Nototheniidae) in the southern Weddell Sea. In: Battaglia B, Valencia J, Walton DWH (eds) Antarctic communities: species, structure and survival. Sixth Biol SCAR Symp, Cambridge University Press, Cambridge, p 277-283

$>$ Hubold G, Tomo AP (1989) Age and growth of Antarctic silverfish Pleuragramma antarcticum Boulenger, 1902, from the Southern Weddell Sea and Antarctic Peninsula. Polar Biol 9:205-212

> Hückstädt LA, Burns JM, Koch PL, McDonald BI, Crocker DE, Costa DP (2012) Diet of a specialist in a changing environment: the crabeater seal along the western Antarctica Peninsula. Mar Ecol Prog Ser 455:287-301

> Jackson S, Place AR (1990) Gastrointestinal transit and lipid assimilation efficiencies in three species of sub-Antarctic seabird. J Exp Zool 255:141-154

Ju SJ, Harvey HR (2004) Lipids as markers of nutritional condition and diet in the Antarctic krill Euphausia superba and Euphausia crystallorophias during austral winter. Deep-Sea Res II 51:2199-2214

> Ju SJ, Kang HK, Kim WS, Harvey HR (2009) Comparative lipid dynamics of euphausiids from the Antarctic and Northeast Pacific Oceans. Mar Biol 156:1459-1473

> Kawaguchi S, Finley LA, Jarman S, Candy SG and others (2007) Male krill grow fast and die young. Mar Ecol Prog Ser 345:199-210

Klinck JM, Hofmann EE, Beardsley RC, Salihoglu B, Howard $S$ (2004) Water-mass properties and circulation on the west Antarctic Peninsula Continental Shelf in austral fall and winter 2001. Deep-Sea Res II 51:1925-1946

Makarov RR, Denys CJ, Group of Specialists on Living Resources of the Southern Ocean (1981) Stages of sexual maturity of Euphausia superba Dana. BIOMASS Handbook No. 11. SCAR, Cambridge

Marrari M, Daly KL, Timonin A, Semenova T (2011) The zooplankton of Marguerite Bay, Western Antarctic Peninsula - Part I: abundance, distribution, and population response to variability in environmental conditions. Deep-Sea Res II 58:1599-1613

Martinson DG, Stammerjohn SE, Iannuzzi RA, Smith RC, Vernet M (2008) Western Antarctic Peninsula physical oceanography and spatio-temporal variability. Deep-Sea Res II 55:1964-1987

Mauchline J (1970) Measurement of body length of Euphausia superba Dana. BIOMASS Handbook No. 4. SCAR/ SCOR/IABO/ACMRR, Cambridge

Mayzaud P, Boutoute M, Alonzo F (2003) Lipid composition of the euphausiids Euphausia vallentini and Thysanoess macrura during summer in the Southern Indian Ocean. Antarct Sci 15:463-475

> McClatchie S, Boyd CM (1983) Morphological study of sieve efficiencies and mandibular surfaces in the Antarctic krill, Euphausia superba. Can J Fish Aquat Sci 40: 955-967

McDaniel JD, Emslie SD (2002) Fluctuations in Adélie penguin prey size in the mid to late Holocene, north Marguerite Bay, Antarctic Peninsula. Polar Biol 25:618-623

> Montes-Hugo M, Doney SC, Ducklow HW, Fraser W, Martinson D, Stammerjohn SE, Schofield O (2009) Recent changes in phytoplankton communities associated with rapid regional climate change along the Western Antarctic Peninsula. Science 323:1470-1473

Nagy KA, Obst BS (1992) Food and energy-requirements of Adélie penguins (Pygoscelis adeliae) on the Antarctic Peninsula. Physiol Zool 65:1271-1284

> Nordhausen W (1992) Distribution and growth of larval and adult Thysanoessa macrura (Euphausiacea) in the Bransfield Strait Region, Antarctica. Mar Ecol Prog Ser 83: 185-196

> Peck LS, Webb KE, Bailey DM (2004) Extreme sensitivity of biological function to temperature in Antarctic marine species. Funct Ecol 18:625-630

> Pinkerton MH, Forman J, Bury SJ, Brown J, Horn P, O'Driscoll RL (2013) Diet and trophic niche of Antarctic silverfish Pleuragramma antarcticum in the Ross Sea, Antarctica. J Fish Biol 82:141-164

Poerschmann J, Carlson R (2006) New fractionation scheme for lipid classes based on 'in-cell fractionation' using sequential pressurized liquid extraction. J Chromatogr A 1127:18-25

> Prézelin BB, Hofmann EE, Mengelt C, Klinck JM (2000) The linkage between Upper Circumpolar Deep Water (UCDW) and phytoplankton assemblages on the west Antarctic Peninsula continental shelf. J Mar Res 58:165-202

> Ross RM, Quetin LB, Martinson DG, Iannuzzi RJ, Stammerjohn S, Smith RC (2008) Palmer LTER: patterns of distribution of five dominant zooplankton species in the epipelagic zone west of the Antarctic Peninsula, 1993-2004. Deep-Sea Res II 55:2086-2105

Schmidt K, Atkinson A, Steigenberger S, Fielding S and others (2011) Seabed foraging by Antarctic krill: implications for stock assessment, bentho-pelagic coupling, and the vertical transfer of iron. Limnol Oceanogr 56:1411-1428 
Schmidt K, Atkinson A, Pond DW, Ireland LC (2013) Feeding and overwintering of Antarctic krill across its major habitats; the role of sea ice cover, water depth, and phytoplankton abundance. Limnol Oceanogr 59:17-36

Smith RC, Fraser WR, Stammerjohn SE (2003) Climate variability and ecological response of the marine ecosystem in the Western Antarctic Peninsula (WAP) region. In: Greenland D, Goodin DG, Smith RC (eds) Climate variability and ecosystem response at long-term ecological research sites. Oxford University Press, New York, NY, p 158-173

Smith CR, Mincks S, DeMaster D (2008) The FOODBANCS project: introduction and sinking fluxes of organic carbon, chlorophyll-a and phytodetritus on the Western Antarctic Peninsula continental shelf. Deep-Sea Res II 55:2404-2414

Stammerjohn SE, Martinson DG, Smith RC, Iannuzzi RA (2008) Sea ice in the Western Antarctic Peninsula region: spatio-temporal variability from ecological and climate change perspectives. Deep-Sea Res II 55:2041-2058

Stammerjohn SW, Masson R, Rind D, Martinson D (2012) Regions of rapid sea ice change: an inter-hemispheric seasonal comparison. Geophys Res Lett 39:L06501, doi: 10.1029/2012GL050874

Steinberg DK, Martinson DG, Costa DP (2012) Two decades of pelagic ecology of the Western Antarctic Peninsula. Oceanography 25:56-67

Torres JJ, Donnelly J, Hopkins TL, Lancraft TM, Aarset AV, Ainley DG (1994) Proximate composition and overwintering strategies of Antarctic micronektonic Crustacea.
Mar Ecol Prog Ser 113:221-232

Trivelpiece WZ, Hinke JT, Miller AK, Reiss CS, Trivelpiece SG, Watters GM (2011) Variability in krill biomass links harvesting and climate warming to penguin population changes in Antarctica. Proc Natl Acad Sci USA 108: 7625-7628

> Van de Waal DB, Verschoor AM, Verspagen JMH, van Donk E, Huisman J (2010) Climate-driven changes in the ecological stoichiometry of aquatic ecosystems. Front Ecol Environ 8:145-152

Vaughan DG, Marshall GJ, Connolley WM, Parkinson C and others (2003) Recent rapid regional climate warming on the Antarctic Peninsula. Clim Change 60:243-274

> Ventura M (2006) Linking biochemical and elemental composition in freshwater and marine crustacean zooplankton. Mar Ecol Prog Ser 327:233-246

> Vernet M, Martinson D, Iannuzzi R, Stammerjohn S and others (2008) Primary production within the sea-ice zone west of the Antarctic Peninsula: I - Sea ice, summer mixed layer, and irradiance. Deep-Sea Res II 55:2068-2085

Westerheim SJ, Ricker WE (1979) Reply to comment on 'Bias in age-length keys.' J Fish Res Board Can 36:1160-1161

- Wiebe PH, Ashjian CJ, Lawson GL, Piñones A, Copley NJ (2011) Horizontal and vertical distribution of euphausiid species on the Western Antarctic Peninsula U.S. Globec Southern Ocean study site. Deep-Sea Res II 58:1630-1651

> Wöhrmann APA, Hagen W, Kunzmann A (1997) Adaptations of the Antarctic silverfish Pleuragramma antarcticum (Pisces: Nototheniidae) to pelagic life in high-Antarctic waters. Mar Ecol Prog Ser 151:205-218

Appendix 1. Relationships between environmental and temporal parameters. Regression statistics for the relationship between latitude (decimal degrees, DD), day of the year, $0-120$ m mean water temperature $\left({ }^{\circ} \mathrm{C}\right.$ ), and $0-120 \mathrm{~m}$ integrated chl $a\left(\mathrm{mg} \mathrm{m}^{-2}\right)$. Regression equations are in linear form: $y=m(x)+b \cdot \mathrm{R}^{2}$ values are presented with corresponding $\mathrm{p}$-values for all significant relationships (where $\mathrm{p} \leq$ 0.05); ns, not significant. Regressions are for combined 2009 and 2010 data. See also Fig. 5

\begin{tabular}{|c|c|c|c|c|c|c|c|c|c|c|c|c|}
\hline & \multicolumn{4}{|c|}{ Water temperature } & \multicolumn{4}{|c|}{ Day of the year } & \multicolumn{4}{|c|}{$0-120 \mathrm{~m}$ integrated $\mathrm{chl} a\left(\mathrm{mg} \mathrm{m}^{-2}\right)$} \\
\hline & $\mathrm{R}^{2}$ & $\mathrm{p}$ & $m$ & $b$ & $\mathrm{R}^{2}$ & $\mathrm{p}$ & $m$ & $b$ & $\mathrm{R}^{2}$ & $\mathrm{p}$ & $m$ & $b$ \\
\hline Latitude (DD) & 0.47 & $<0.0001$ & -0.24 & 15.82 & 0.46 & 0.0001 & 2.60 & -157.81 & 0.20 & 0.018 & 15.69 & -964.54 \\
\hline $\begin{array}{l}\text { 0-120 m mean } \\
\text { water temp }\left({ }^{\circ} \mathrm{C}\right)\end{array}$ & & & & & 0.17 & 0.034 & -4.43 & 14.35 & 0.20 & 0.019 & -0.005 & 0.05 \\
\hline Day of the year san & oled & & & & & & & & & $0.16, \mathrm{~ns}$ & 0.03 & 13.21 \\
\hline
\end{tabular}

Editorial responsibility: Edward Durbin, Narragansett, Rhode Island, USA
Submitted: November 11, 2013; Accepted: May 15, 2014 Proofs received from author(s): August 2, 2014 